Esteve Rico, Sergi. La invasión urbanística en el término municipal de Castalla (Alicante): el descontrol del poblamiento diseminado ilegal. GeoGraphos [En línea]. Alicante: Grupo Interdisciplinar de Estudios Críticos y de América Latina (GIECRYAL) de la Universidad de Alicante, 3 de Octubre de 2014, vol. 5, $\mathrm{n}^{\mathrm{o}}$ 72, p. 400-447. [ISSN: 2173-1276] [DL: A 371-2013] [DOI: 10.14198/GEOGRA2014.5.72].

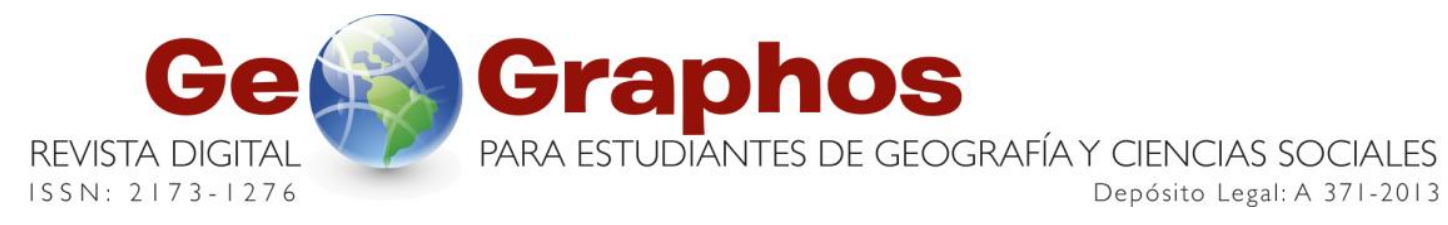

〈http://web.ua.es/revista-geographos-giecryal〉

\title{
LA INVASIÓN URBANÍSTICA EN EL TÉRMINO MUNICIPAL DE CASTALLA (ALICANTE): EL DESCONTROL DEL POBLAMIENTO DISEMINADO ILEGAL
}

\author{
Sergi Esteve Rico \\ Grado en Geografía y Ordenación del Territorio \\ Facultad de Filosofía y Letras. Universidad de Alicante (Alicante, España) \\ Correos electrónicos: ser7@alu.ua.es y sergiesteverico@gmail.com
}

Recibido: 2 de septiembre de 2014. Aceptado: 3 de octubre de 2014

\section{RESUMEN}

Durante los años de burbuja inmobiliaria la construcción se convirtió en actividad económica destacada en toda España, pero en especial en las zonas de desarrollo turístico del litoral mediterráneo. En ese contexto, y aprovechando el auge del residencialismo en las zonas prelitorales todavía ajenas a la masificación de la primera línea de playa, el municipio de Castalla (Alicante) se vio inmerso en un desarrollo de la construcción impulsado principalmente por las corporaciones municipales, y del que tres vertientes sobresalen: la construcción de una gran urbanización, la ampliación del núcleo de Castalla en varios sectores urbanizables, y la acentuación de un fenómeno arraigado desde tiempo atrás como es el poblamiento diseminado. Los visos de ilegalidades y las sospechas de corrupción no quedan al margen de este proceso, que una vez reventada la burbuja muestra las cicatrices de una pésima planificación urbanística en un territorio que ahora presenta enormes dificultades de cara a la gestión.

Palabras clave: Residencialismo, urbanismo, poblamiento diseminado, burbuja inmobiliaria, corrupción, planificación urbana. 


\title{
THE URBAN INVASION IN THE TOWN OF CASTALLA (ALICANTE, SPAIN): THE LACK OF CONTROL OF THE SCATTERED ILEGAL SETTLEMENT
}

\begin{abstract}
Construction became a prominent economic activity in Spain during the property bubble years, but especially in the areas of tourism development on the Mediterranean coast. In this context, and taking advantage of the boom of the residential tourism in the precoastal areas still outside the overcrowding of the beach-front, the town of Castalla (Alicante, Spain) was immersed in a construction development mainly driven by municipal corporations, and of which three aspects stand out: the construction of a large housing development, the extension of the nucleus of Castalla in several developable areas, and the accentuation of a phenomenon rooted from long ago as it is the scattered settlement. The overtones of illegalities and the suspicions of corruption aren't apart from this process that once the bubble burst, shows the scars of a dismal urban planning in a territory that now shows enormous difficulties facing the management.
\end{abstract}

Keywords: Residential Tourism, Urbanism, Scattered Settlement, Property Bubble, Corruption, Urban Planning.

\section{A INVASÃO URBANA NA CIDADE DE CASTALLA (ALICANTE, ESPANHA): A FALTA DE CONTROLO DE ESTABELECEMENTOS DISPERSOS E ILEGAIS}

\section{RESUMO}

Construção tornou-se uma actividade económica de destaque na Espanha durante os anos da bolha imobiliária, mas especialmente nas áreas de desenvolvimento turístico na costa do Mediterrâneo. Neste contexto, e aproveitando o boom do turismo residencial em áreas pré-costeiras ainda fora da superlotação da praia, a cidade de Castalla (Alicante, Espanha) foi imersa em uma construção de desenvolvimento impulsionada principalmente por empresas municipais, em que três aspectos se destacam: a construção de um grande conjunto habitacional, a extensão do núcleo de Castalla em diversas áreas de desenvolvimento, e a acentuação de um fenómeno enraizado de há muito tempo, como é a construção dispersa. Os tons de ilegalidades e as suspeitas de corrupção não estão para além deste processo, pois assim que a bolha estoirou, expôs-se as cicatrizes de um planeamento urbano sombrio em um território que agora mostra enormes dificuldades enfrentadas pela gestão.

Palavras-chave: Turismo residencial, urbanismo, construção dispersa, bolha imobiliária, corrupção, planeamento urbano. 


\section{INTRODUCCIÓN}

El municipio de Castalla se ubica en el interior norte de la provincia de Alicante, a poco más de 30 kilómetros de la capital provincial. Se emplaza en la llamada Hoya de Castalla, un sector llano a una altitud que ronda los 600 metros sobre el nivel del mar y que destaca por estar rodeado de relieves montañosos que superan con holgura los 1.000 msnm. Castalla linda con Onil al norte; Ibi al noreste; Jijona y Tibi al este; Agost y Petrer al sur; y Sax y Biar al oeste. De este modo, comparte con Ibi, Onil y Tibi la Hoya de Castalla, también conocida como el Valle del Juguete.

\section{Figura 1. Localización de Castalla y su término municipal en la provincia de Alicante}

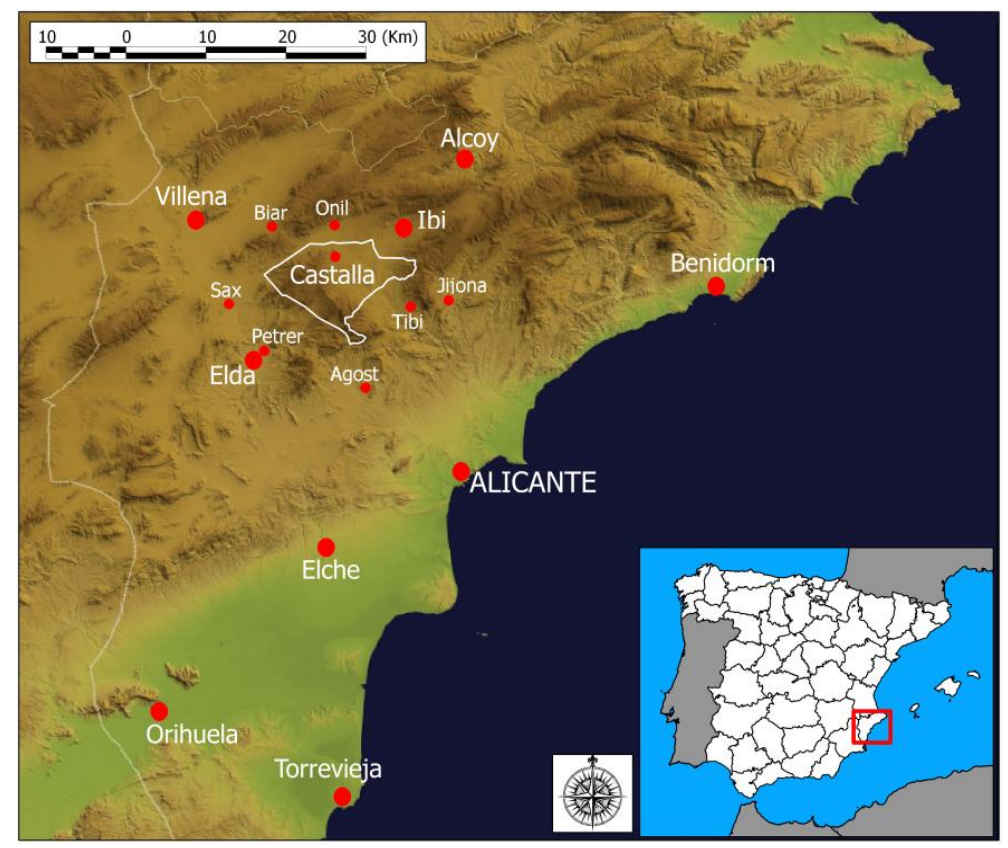

Fuente: Terrasit. Elaboración propia

Según el Padrón Municipal de Habitantes de 2013 el municipio de Castalla cuenta con 10.579 vecinos, siendo así el trigésimo octavo municipio de la provincia en número de habitantes (sobre un total de 141). Sin embargo cabe destacar que la población del municipio se distribuye principalmente entre dos núcleos de población, con lo que 8.466 habitantes residen en el núcleo de Castalla, capital municipal, y otros 1.060 habitantes lo hacen en la urbanización "Els Campellos", también conocida como "Castalla Internacional"; los 1.053 habitantes restantes residirían, según el Nomenclátor, en el poblamiento diseminado. Con estos datos en la mano y aplicando un criterio estrictamente estadístico, no se podría considerar a los castallenses como población urbana dado que ninguno de los núcleos del término supera los 10.000 habitantes que se utilizan en España como definición de la población urbana. 


\section{Realidad económica reciente y actual de Castalla}

En lo referente a la economía del municipio destaca especialmente el peso del sector servicios, seguido del secundario, una realidad en la que tiene mucho que ver la crisis que arrastra el sector industrial y que se ha agravado con la actual crisis económica. El tradicional peso de la industria en la economía de Castalla ha necesariamente de vincularse con la tradición juguetera de la comarca, que desde antes de la Guerra Civil Española ya vivía una auténtica edad de oro favorecida por el éxito de los juguetes de lata que producía. Obviamente la contienda frenó bruscamente la producción de juguetes y provocó una decadencia en el sector que se invertiría llegados los años 1950 y la incorporación del plástico en esta industria, lo que propició una gran diversificación de producción, que junto con la reducción de costes supuso una auténtica eclosión de talleres auxiliares. Con la expansión de la economía comarcal y el progresivo abandono del campo que supuso el éxodo rural en la España de la segunda mitad del siglo XX, la Hoya de Castalla recibió grandes aportes de población proveniente fundamentalmente de Albacete, Murcia, Granada y Ciudad Real, lo que se refleja en el aumento de la población hispanohablante en la comarca en detrimento de los catalanohablantes, rasgo evidente de riqueza cultural.

\section{Figura 2. Distribución de los empleos por sector económico en Castalla. Años} 2006-2013

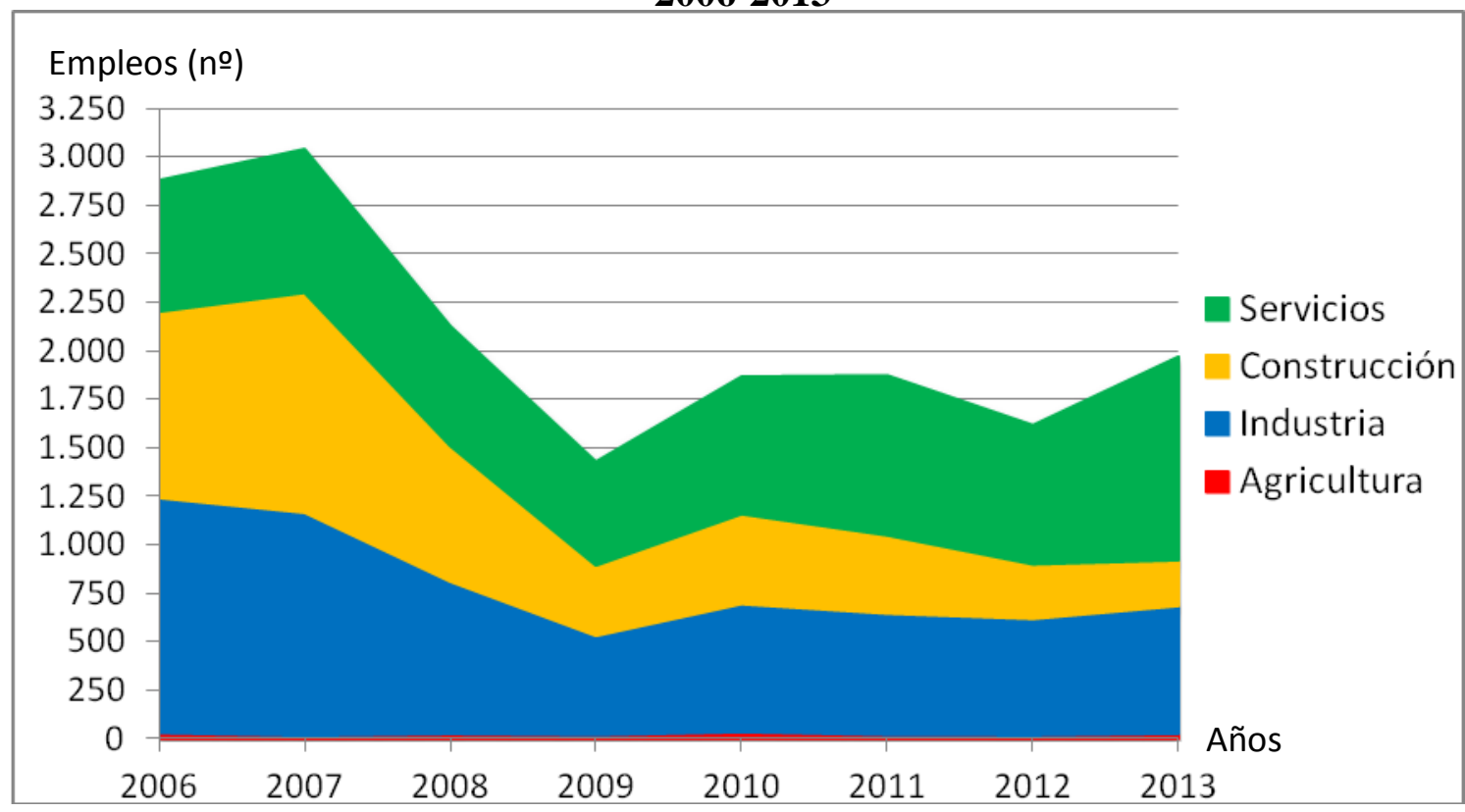

Fuente: IVE. Banco de datos territorial, movimiento laboral registrado. Contratos según actividad económica (CNAE-1993 y CNAE-2009). Elaboración propia.

*(Nota: A partir del mes de marzo de 2009 se emplea la Clasificación Nacional de Actividades Económicas 2009, lo que supone una modificación en la distribución de sectores económicos respecto a períodos anteriores en los que se utilizaba la CNAE-1993.)

Sería a partir de los años 1980 y sobre todo 1990 cuando el sector alcanzaría un estadio de madurez que haría aflorar una serie de problemas ocultos hasta el momento por el auge económico, y que se resumen en la falta de inversión continuada en I+D+i y la falta de planificación que suavizase los efectos de una demanda muy concentrada en los meses previos a la navidad; con ello llegó una creciente deslocalización hacia países del 
sureste asiático en busca de las ventajas comparativas de aquellos países para recuperar así una competitividad que empezaba a flojear. El resultado fue una previsible pérdida de empleo en el sector, que en muchos casos no terminó de evidenciarse en los registros de empleo dado que coincidió con el auge económico de la burbuja inmobiliaria, y favoreció un trasvase de la mano de obra a la construcción (eminentemente masculina, con hasta el 37,17\% del mercado laboral de Castalla en 2007) y sectores asociados, además de una creciente terciarización laboral. Sería la crisis económica de finales de los años 2000 la que provocaría una auténtica sangría de empleos tanto en Castalla como en su entorno regional y en el resto del país; para el caso del municipio destaca cómo se redujo drásticamente el sector de la construcción y cómo se sumaba a la crisis de la industria, colocando en pocos años a los servicios a la cabeza de la economía castallense.

En este mismo sentido cabe apuntar que, además de la industria del juguete, la economía castallense de finales de los años 1990 y durante los 2000 se ha apoyado fuertemente, por ejemplo, en otros sectores relacionados en mayor o menor medida a la urbanización como son las empresas de mobiliario. Así, destacan empresas locales como Puertas Castalla S.L., que se dio a conocer a nivel nacional anunciándose en las vallas publicitarias de los estadios de fútbol de la Liga de Fútbol Profesional (LFP) durante varias temporadas; Ripay S.A., con importante presencia en el mobiliario de hostelería; o Actiu S.A., especializada en el mobiliario de oficina y con un parque tecnológico en el término de Castalla que supone un motor económico de primer orden.

Probablemente uno de los fenómenos laborales, económicos y fiscales que mayor preocupación suscite a los ministerios de Hacienda y Empleo (e idéntica reacción debería causar entre todos los ciudadanos) sea la existencia de grandes bolsas de economía sumergida, con las repercusiones sobre el empleo que esto conlleva. No es un fenómeno exclusivo de una región concreta, ni de una comarca, ni de un municipio, sino que las estimaciones existentes (huelga recordar la inexistencia de datos oficiales y exactos sobre este particular, por razones obvias) lo establecen como un fenómeno más bien generalizado.

Especialmente reveladora en este sentido resultaba la noticia publicada en mayo de 2014 por el diario Información en la que se advertía que la Inspección de Trabajo había detectado empleo irregular en 2.990 del total de 11.453 inspecciones (26'11\%) realizadas en la provincia de Alicante durante el año 2013. Según esta información destacarían entre las irregularidades encontradas los trabajadores sin contrato, los que realizaban más horas de las declaradas, y los que desarrollaban tareas distintas a aquéllas por las que se les había contratado. Es un dato que está plenamente en consonancia con lo que recogería la EPA del primer trimestre de 2014, que revelaba la presencia de hasta 100.796 trabajadores alicantinos que no estarían dados de alta en la Seguridad Social en ese año, el registro más elevado del país.

Por sectores, en el contexto de la provincia destaca la industria por registrar el mayor porcentaje de inspecciones en las que se detectó irregularidad. Quizás entre los datos el que más llamativo resulte sea el de la construcción, que registra el porcentaje más bajo entre los sectores (aun situándose en un 16\% $6 \%$ de las inspecciones con alguna irregularidad detectada). 
Se trata de un fraude cuyas ramificaciones se extienden hasta otros ámbitos como el de las prestaciones. El mismo artículo recoge la detección por parte de las autoridades de hasta 2.430 infracciones de este tipo en la provincia de Alicante entre 2012 y 2013.

Nótese que si bien en el caso de la EPA los datos los ofrece una encuesta (perfectamente homologada y con una muestra grande, pero una encuesta al fin y al cabo), los datos de las inspecciones resulta, por absoluto e incuestionable, escandaloso, más aun sabiendo que esas inspecciones no logran detectar la totalidad de infracciones que se producen. Una vez más las miradas deben dirigirse a la administración cuando se constata que el número de inspectores es insuficiente; es algo, además, que no parece poder subsanarse con los escasos ochenta inspectores más con que se iba a ampliar la plantilla para todo el país en 2014, según anunciaba el Ministerio de Empleo en mayo de ese mismo año.

En el caso de Castalla se puede afirmar que el empleo sumergido ha existido y sigue existiendo, y según impresiones de los propios castallenses (no habiéndose encontrado estimaciones a nivel municipal sobre este supuesto) habría afectado sobre todo al empleo femenino relacionado con el mundo del juguete, existiendo presumiblemente un gran número de locales particulares, propiedad de las propias empleadas, en los que recibirían las piezas de las muñecas y procederían a su montaje para entregarlas una vez terminadas, con lo que la empresa ahorraría costes de producción al no tener que disponer de las instalaciones necesarias para el proceso ni tener que asumir los costes relacionados con la electricidad que se pudiera requerir. Todo ello acompañado en la práctica totalidad de los casos de un auténtico (y siempre supuesto) fraude a la Seguridad Social al escurrir el pago de cotizaciones sociales y demás costes laborales, e incluso con salarios por unidad de obra. Las consecuencias de este supuesto fraude son evidentes, partiendo de un enriquecimiento muy acentuado de los propietarios de las empresas que llevaban a cabo dicha práctica, sin olvidar los estragos en lo que a tiempo cotizado se refiere, algo que en un primer momento habría importado a más bien pocas trabajadoras por lograr ingresos más o menos seguros (dada la importante carga de trabajo que se supone) y que con el tiempo se traduciría en un auténtico problema futuro de sustento económico cuando estas personas alcancen la edad de jubilación.

En la actualidad más reciente la economía del municipio sigue la tónica general en su entorno más inmediato, con un claro protagonismo de los estragos de la crisis económica desatada desde finales de la década de los 2000 y que suma ya más de un lustro de recorrido. El resultado ha sido una fuerte pérdida de puestos de trabajo tanto en el sector terciario como en el industrial, de especial significación en la comarca como ya se apuntaba con anterioridad, aunque los datos de desempleo deben tomarse con la misma precaución con que deben tomarse para el resto del país dados los elevados índices de economía sumergida que se suponen.

Las actividades primarias, representadas mayoritariamente por la agricultura, tienen un peso meramente testimonial en el conjunto de la economía castallense. Actualmente se mantienen como una actividad complementaria con la que obtener sobre todo productos para consumo propio. Los dos cultivos más extendidos son sin duda el almendro y el olivo, quedando algo eclipsado el cultivo de la vid que en otros tiempos sí tuvo un peso más destacable, fruto sobre todo de las políticas de la PAC que desincentivan la producción tanto de uva de mesa como de vino (la primera de ellas con una fuerte competencia en el valle del Vinalopó que llevaba a que la práctica totalidad del cultivo fuese destinado a vino). De ese modo, es frecuente que los campos de almendros y 
olivares se trabajen apenas durante la época de recogida del fruto, mientras que los pocos cuidados que pudieran requerir durante el resto del año acaban atendiéndose por la población jubilada del municipio, con mucho más raigambre hacia las actividades del campo que las nuevas generaciones, plenamente integradas éstas en el dinamismo industrial y terciario de la zona. Así, la recogida de la almendra y la aceituna acaban instaurándose como poco menos que una tradición familiar que sirve de excusa para reunir a toda la familia durante unos días para trabajar los campos, de extensión modesta y perfectamente asumibles sin necesidad de acudir a mano de obra asalariada. La producción se destina a consumo propio de la familia, siendo frecuente que al menos uno de los miembros esté cooperado y que los propios costes de producción del aceite se paguen en especie.

Cabe señalar también que en las últimas décadas el campo de Castalla se ha visto afectado por el trazado de una de las infraestructuras de comunicaciones más importantes de la zona, y cuyo emplazamiento resulta un testimonio perfectamente ilustrativo de la apuesta por parte de los poderes públicos locales (municipios y diputación) y autonómico por el sector industrial de la Hoya de Castalla frente a los intereses de la agricultura. Así, una de las zonas más fértiles del municipio corresponde a la vega del Río Montnegre (que en estos municipios se conoce todavía como Río Verde) y el marjal que tiempo atrás describía en su nacimiento, entre los términos municipales de Castalla y Onil. Justo esa zona fue atravesada por el recorrido de la autovía que une hoy Alicante, Alcoy y Villena, con un cruce que vertebra la disposición norte-sur y este-oeste justo entre Castalla, Onil e Ibi. Este eje de comunicaciones resulta hoy vital para el desarrollo de la industria de la Hoya de Castalla, dado que conecta no sólo con el que tradicionalmente ha sido polo industrial del interior alicantino (Alcoy) sino que además comunica con la capital provincial, de especial atractivo por su condición portuaria, y con la meseta y el interior español a través de Villena. Primando ese interés estratégico en lo que a industria se refiere (también en cierto modo es un eje interesante para las actividades terciaras en su faceta turística, pero sobre todo destaca por su papel respecto a la industria) se han sacrificado los intereses de la actividad primaria atravesando las tierras más fértiles y productivas del término; de hecho así se advertía ya en el Plan General del Término Municipal de Castalla del año 2002. ${ }^{1}$

\section{CONTEXTO GENERAL DE LA ECLOSIÓN INMOBILIARIA DESDE FINALES DE LA DÉCADA DE LOS AÑOS 1990 HASTA FINALES DE LA DÉCADA DE LOS AÑOS 2000}

\section{El caldo de cultivo idóneo para la creación de la burbuja inmobiliaria}

Encontrar el germen que dio lugar a la explosión urbanística y fijar con él una fecha de inicio se antoja una tarea extremadamente compleja dado que en realidad, como ocurre en otros tantos hitos en la reciente historia económica española, se produjo como resultado de un conjunto de coyunturas económicas y políticas a lo largo de los años. Puestos a encontrar al menos un momento histórico destacado habría que remontarse al

\footnotetext{
${ }^{1}$ Memoria justificativa del Plan General del Término Municipal de Castalla. Portal web de la Conselleria d'Infraestructures, Turisme i Medi Ambient [en línea]. Aprobado el 25 de julio de 2002. [Consulta: 21/05/2014]. Pág.13. Disponible en: <http://www.cma.gva.es/contenidoHtmlArea/contenido/30231/cas/MemInformativa.pdf >
} 
primer gobierno del presidente José María Aznar, una época de privatizaciones ya iniciada en los últimos años de gobierno de Felipe González y con Pedro Solbes al frente de la cartera de economía. Según explica el periodista económico Mariano Guindal (2011, p. 415 y sigs. y p.483 y sigs.) en su libro El declive de los dioses, el objetivo claro del nuevo Ministro de Economía, Rodrigo Rato, y del gabinete Aznar en su conjunto era la entrada de España en la moneda única europea, una entrada que debía producirse además entre los países que lo inauguraran (1 de enero de 1999 en los mercados financieros, en sustitución del ECU). Todo ello venía favorecido por la recuperación económica de los años 1996-1997 (por la premisa de que la recuperación económica tarda entre seis y doce meses en notarse a efectos de empleo, aunque no faltan economistas que alargan algo más este periodo), con crecimientos que rondaban el dos por ciento y creación de decenas de miles de nuevos empleos; todo ello sin que el nuevo gobierno conservador tuviera que hacer nada especialmente destacado para lograrlo, simplemente siguiendo el impulso de aire fresco que suponía un cambio político después de doce años de gobiernos socialistas (una auténtica novedad desde el fin de la dictadura franquista), el buen funcionamiento de la economía mundial y el billón largo de pesetas que inyectaba cada año la UE en España.

Con el buen ritmo de las exportaciones y de la demanda, un déficit conjunto de las administraciones del $3 \%$ y un crecimiento de la economía superior a la suave inflación, se hizo famosa la mítica frase del presidente Aznar: "España va bien". Con esa coyuntura el ministro Rato decidió impulsar un modelo de crecimiento intensivo en mano de obra, apoyado fundamentalmente en la construcción y los servicios. El objetivo era el pleno empleo, primando la cantidad sobre la calidad, con la intención de crear el caldo de cultivo económico idóneo para lograr en las elecciones del año 2000 la mayoría absoluta para el Partido Popular que no se había logrado en las elecciones de 1996 y que había dejado un sabor agridulce en el partido. Así, con los tipos de interés a la baja, los incrementos salariales al alza y la creación sostenida de empleo fijo (hasta cuatro millones entre 1996 y 2002, acompañado por una de las productividades más bajas de la historia económica de España) el Ministerio impulsó una serie de políticas procíclicas fundamentadas en la inyección de 700.000 millones de pesetas a las familias con una reducción de impuestos en 1998, lo que hizo crecer el PIB hasta niveles del $5^{\prime} 6 \%$, propios del desarrollismo.

El entonces gobernador del Banco de España alertaba del recalentamiento de la economía y proponía enfriarla a base de recortar el gasto público y acumular superávit presupuestario en previsión de futuras recesiones, medidas propias de una política anticlíclica totalmente contraria a la adoptada por el Ministerio. El ministro Rato consideraba que había que frenar el crédito inmobiliario para pinchar la burbuja antes de que tomara calibres desmesurados, pero sabía que atender las recomendaciones del Banco de España resultaba, políticamente hablando, absolutamente desaconsejable. Así, se limitó a pedir ante la Confederación Española de Cajas de Ahorros (CECA) que se frenasen los créditos hipotecarios, con escasos resultados. De nuevo en 2002 el Banco de España advertía de que el precio de las viviendas estaba sobrevalorado en un $20 \%$, pero el Gobierno no quiso reaccionar y atender una realidad que empezaba a cobrar tintes preocupantes. 


\section{Un fenómeno que dista mucho de ser endémico}

El modelo de especulación urbanística no se puede considerar como genuino de nuestro país. Según testimonio recogido del economista Manuel Lagares en la obra de Mariano Guindal, El declive de los dioses, el detonante de toda la máquina de créditos hipotecarios que estalló con la crisis financiera internacional habría que encontrarlo en Estados Unidos, el 11 de septiembre de 2001. Tras los atentados del World Trade Center el gobierno republicano de George W. Bush emprendió una auténtica cruzada supuestamente contra el terrorismo islamista radical que tomó su máxima expresión con la guerra de Irak. Los costes económicos de la contienda llevaron a las arcas estadounidenses a registrar un notable déficit fiscal que se unía al déficit comercial del país en una coyuntura de deslocalización estratégica en la que, si bien se recibían ingresos por patentes, se tenían que importar los bienes fabricados en el exterior. Para solventar el desajuste Estados Unidos invadió el mercado con bonos, con un mecanismo que no era otro que el de ofrecer créditos hipotecarios a los ciudadanos, los necesitasen o no, los pudiesen pagar o no, con la intención de que el ciudadano adquiriese vivienda sabiendo que haciéndolo en el año 2000 la podría vender por el doble apenas cinco años después, recuperando la inversión, más los intereses, más un beneficio generado por la revalorización del suelo. Además, según la Ley hipotecaria estadounidense si la jugada no salía bien era el banco el que asumía el quebranto a través de la figura de la dación.

Obviamente el modelo estadounidense tardó poco en extrapolarse también en España aprovechando la rápida revalorización del suelo, pese a las advertencias del Banco de España sobre el riesgo de suscribir hipotecas con tipo variable como estaba ocurriendo masivamente. El Gobierno en lugar de enfriar la economía como se recomendaba desde el Banco de España decidió recalentarla y aprovechar la cresta de la ola, aplicando una fuerte desgravación fiscal por compra de primera vivienda. Como recoge Mariano Guindal en su libro, el que fuera Secretario de Estado de Economía durante la primera legislatura de Aznar (1996-2000) y mano derecha del Ministro Rodrigo Rato, y posterior Ministro de Hacienda en la segunda legislatura de Aznar (2000-2004), Cristóbal Montoro, atribuía el desastre inmobiliario español al crecimiento de la renta de las familias que se produjo durante la época de bonanza de finales de los años $1990 \mathrm{y}$ principios de los 2000, al paralelo crecimiento del empleo, a la llegada masiva de inmigración y a la entrada de España en el Euro, lo que armonizó su economía con la del resto de Europa y facilitó que clases medias y altas de la Europa central y nórdica quisiera comprar vivienda en la ribera mediterránea atraídos por el buen clima.

Hay otros dos factores que hay que considerar en el cóctel para comprender la complejidad del fenómeno: por un lado, la sentencia de 1997 del Tribunal Constitucional sobre las competencias en materia de suelo, y por otro la aparición de una burbuja de empleo paralela a la financiera y la inmobiliaria.

\section{Competencias, falta de control y eclosión de la corrupción. Daños colaterales del boom inmobiliario}

En efecto, en 1997 el Tribunal Constitucional determinaba que las competencias en materia de suelo correspondían estrictamente a autonomías y ayuntamientos, lo que por un lado aliviaba al Gobierno central de gestionar un ámbito que se sabía iba a traer problemas en un futuro no muy lejano, y que al mismo tiempo dejaba un negocio tan sumamente jugoso en manos, sobre todo, de los más de ocho mil ayuntamientos con que 
cuenta España, lo que complicaba sobremanera el control del buen hacer de los trabajadores y cargos públicos por parte de las instancias superiores. Con el sistema de clasificación y calificación de suelos dispuesto a libre criterio de los ayuntamientos se acentuó el encarecimiento artificial del suelo, un instrumento que en muchas ocasiones se utilizó con intereses partidistas y personales por parte de concejales y alcaldes, tramándose auténticas redes de influencias y amistades que desembocaron en una auténtica marea de casos de corrupción que salpicó a la práctica totalidad del territorio nacional, y a una enorme variedad de partidos.

En este sentido, resulta imprescindible rescatar el trabajo de los investigadores del Departamento de Geografía de la Universidad de La Laguna (Tenerife, Islas Canarias, España), Aproximación a una geografía de la corrupción urbanística en España. Si bien es cierto que la corrupción no es un fenómeno que acompaña exclusivamente a las actividades urbanísticas, igualmente se puede afirmar que en los últimos años el principal foco de corrupción en España ha estado siempre cercano a la actividad urbanística y a los agentes y poderes que orbitan a su alrededor. El minucioso análisis expuesto en el trabajo antes citado resulta tan clarividente que merece traerse aquí un resumen así como las cifras más significativas del problema, que sin duda despejan cualquier tipo de duda respecto de la vinculación o no entre corrupción y actividad urbanística en los últimos años, y que por tanto justifica su mención en este trabajo. El artículo de los investigadores canarios recuerda que si bien España representa un 10\% del PIB europeo, la cantidad de viviendas que ha construido desde el año 2000 alcanza el 30\% del total de viviendas construidas en toda la Unión Europea. Es un dato que podría llevarnos a pensar que si la corrupción y el fenómeno urbanístico están en los últimos años estrechamente entrelazados la conclusión que debe desprenderse es que la corrupción se instaura como una suerte de endemismo propio de nuestro país. Como bien se demuestra en el artículo, no es cierto, pero sí llama la atención que parece ser el común denominador de aquellos países periféricos de la Unión que han venido a llamarse PIGS ("cerdos" en inglés, aunque también se encuentra escrito "PIIGS") por las siglas que componen sus nombres (Portugal, Irlanda e Italia, Grecia y España Spain-), y que resultan ser los países que con mayores dificultades han afrontado la crisis financiera internacional en el marco de la UE (Jerez, Martín y Pérez, 2012).

Tal y como explican los investigadores canarios, cabe apuntar, no obstante, que la corrupción se manifiesta de formas distintas en cada uno de estos países. En Portugal aparece con fuerza en el ámbito del municipalismo, rasgo que compartiría con España, y encuentra su arraigo en los intercambios de favores, el clientelismo de los partidos políticos, o la imbricación entre poderes políticos y económicos. Mientras, en Grecia el problema asume tintes extremadamente preocupantes, hasta el punto de que organismos como Transparencia Internacional la califiquen de "sistemática" a lo largo y ancho de todo el aparato administrativo, con especial incidencia en lo que a consecución de licencias se refiere, para acelerar trámites, saltarse listas de espera o manipular los resultados de las inspecciones fiscales, todo ello con el soborno como figura que lo materializa. Las cifras que se ofrecen son delatadoras, el informe de Transparencia Internacional habla de hasta $1.355 €$ por griego y año que habría ido a parar a funcionarios corruptos, y hasta $1.671 €$ por griego y año que terminaría en manos corruptas del sector privado, donde también está extendido el fenómeno. Y quizás especialmente preocupante por su faceta ecológica sea la vinculación que se plantea entre los incendios que verano tras verano asolan el país (especialmente virulento fue el estío de 2007) tras los cuales habría intereses por liberar suelos que destinar a la 
actividad urbanística por parte de promotores, especuladores y constructoras, aprovechando un descontrol burocrático y legal en materia de suelo que propicia este tipo de atropellos. Es un fenómeno éste que se sospecha también se produce en nuestro país con los devastadores incendios que se suceden verano tras verano. En Irlanda, por otra parte, el problema urbanístico iba ligado al frenesí crediticio en el que fácilmente se expedían préstamos hasta a treinta años, tanto a compradores como a constructores. El resultado fue el colapso financiero que terminó en la intervención (comúnmente se habla de "rescate") por parte de la Unión Europea y el Fondo Monetario Internacional.

En España, las dimensiones del fenómeno de la corrupción pueden considerarse como abismales sin riesgo de pecar de exagerados. Sin duda hay que "agradecer" (valga la ironía) al Caso Malaya, destapado en 2006 y con centro en la malagueña Marbella, el haber puesto rostro al monstruo de la corrupción que se había extendido silenciosa pero eficazmente por todo el territorio nacional. A partir de ese momento, como explican los investigadores canarios, la corrupción empieza a llenar páginas en los periódicos, mostrando a la ciudadanía un auténtico mundo de corruptelas, enriquecimientos turbios y mal uso de los cargos públicos, y con ello la preocupación ciudadana por la gestión pública ha ido creciendo hasta establecerse en los primeros puestos en las encuestas del CIS a este respecto ${ }^{2}$. Tanto es así que el estudio recoge un total de 414 casos en municipios distintos entre 2006 y 2008, con otros 262 casos entre los años 2009 y 2010. En total, 676 municipios (un 8,3\% del total) se habrían visto salpicados por algún caso de corrupción, cifra que asume proporciones escandalosas si se mide en número de habitantes que habrían visto cómo en su administración más cercana, la municipal, se habían cocido entramados corruptos, llegando hasta los 23,3 millones de españoles, un $56,1 \%$ del total.

En lo referente a la localización, destacan sin duda los enclaves cercanos al litoral por el componente turístico tan fuerte que en los últimos años impulsaría la construcción. Cifras tan delatadoras como que un tercio de los casos se dan en municipios litorales, o que hasta el $78 \%$ de las capitales de provincia o regionales cuentan con algún caso, llegando a copar una cuarta parte del total de los casos si se consideran las capitales junto con sus periferias. De igual modo destacan las conclusiones a efectos económicoterritoriales, con hasta el 42,3\% de los casos en municipios de tradición agraria (lo que entenderíamos como municipios rurales, y por tanto Castalla es un buen ejemplo) en los que la construcción irrumpió con fuerza en los años del boom, y hasta el 21,7\% de los casos en ciudades y el 13,3\% en municipios turísticos.

Hay un último apartado en el estudio que relaciona corrupción (vinculada al urbanismo) y los partidos políticos, y que resulta especialmente interesante a la hora de abordar el caso del auge de la construcción en el municipio de Castalla. Para empezar se advierte la frecuencia con la que coincide que los ayuntamientos en los que se detecta corrupción concuerdan en signo político con los gobiernos regionales. Además, los datos que ofrece el trabajo hablan de tres cuartas partes de los casos que salpicarían a partidos nacionales (PP, PSOE e IU; no así UPyD que nace con posterioridad y no alcanza un

\footnotetext{
${ }^{2}$ En las encuestas de octubre de 2013 a enero de 2014 tanto la clase política como la corrupción aparecen entre los cuatro primeros asuntos, entremezclados con el paro y los problemas de índole económica; buena muestra de hasta qué punto, en una época de estrechez económica como la actual, interesa a la ciudadanía el buen hacer (o no) de sus representantes políticos.

Barómetros del CIS, octubre de 2013 a enero de 2014. [Consulta: 22/04/2014]. Disponibles en:

<http://www.cis.es/cis/opencm/ES/11 barometros/preguntasfijas.jsp >
} 
cuerpo considerable hasta ya bien entrada la crisis), con un $44 \%$ de casos que afectarían al partido conservador y un $31,2 \%$ de los mismos correspondiente a los socialistas. Especialmente preocupante resulta la siguiente reflexión de los autores, reproducida aquí literalmente:

"Se debe tener en cuenta que la mayor parte de los casos de corrupción urbanística comenzaron a denunciarse a partir de 2006, cuando el Gobierno central estaba en manos del PSOE. Ello explica en parte la cierta diferencia entre los casos de corrupción de este partido y el PP." (Jerez, Martín y Pérez, 2012, p.15).

Si la interpretación que se hace de la misma tiene que ver con la posible utilización partidista de órganos del Estado como la propia Fiscalía, el escándalo público que debería derivarse se justifica por sí solo. Desde luego si la sospecha que parece desprenderse de las líneas arriba reproducidas es la que aquí se interpreta, y estuviera en lo cierto, nos encontraríamos ante un clarísimo ejemplo de la necesidad de una renovación política que terminase con cualquier viso de apropiación política de los instrumentos del Estado con fines partidistas, especialmente si ello se tradujese en acoso y persecución por parte del partido del Gobierno (sea cual sea) hacia los partidos de la oposición en busca de asuntos turbios con los que atacar mientras se esconden los propios. Unas actitudes que casan muy mal con la propia esencia de la Democracia, tan necesitada por otra parte en el caso español de una urgente revisión y una depuración profunda que se traduzca en la imprescindible renovación y adaptación de las piezas del sistema democrático a la coyuntura actual, abordando los manifiestos defectos que se han demostrado en episodios de dificultades como las que actualmente atraviesa el país.

Cuadro 1. Casos de corrupción urbanística municipal por comunidades autónomas en España (izquierda) y porcentaje de municipios de las comunidades autónomas afectados por casos de corrupción urbanística (derecha), entre los años 2000 y 2010

\begin{tabular}{|c|c|c|c|}
\hline Comunidad autónoma & $\mathrm{N} .^{\circ}$ de municipios afectados & Comunidad autónoma & $\begin{array}{c}\text { \% municipios afectados/ } \\
\text { total de municipios }\end{array}$ \\
\hline Andalucía & 154 & Murcia & 57,8 \\
\hline Valencia & 94 & Canarias & 39,8 \\
\hline Galicia & 66 & Baleares & 35,8 \\
\hline Madrid & 46 & Asturias & 26,9 \\
\hline Cataluña & 43 & Madrid & 25,7 \\
\hline Castilla y León & 40 & Galicia & 20,9 \\
\hline Canarias & 35 & Andalucía & 20,0 \\
\hline Extremadura & 29 & Cantabria & 17,6 \\
\hline Castilla-La Mancha & 27 & Valencia & 17,3 \\
\hline Murcia & 26 & Extremadura & 7,5 \\
\hline Baleares & 24 & País Vasco & 7,1 \\
\hline Asturias & 21 & La Rioja & 6,9 \\
\hline Cantabria & 18 & Navarra & 5,1 \\
\hline País Vasco & 18 & Cataluña & 4,5 \\
\hline Navarra & 14 & Castilla-La Mancha & 2,9 \\
\hline La Rioja & 12 & Castilla y León & 1,8 \\
\hline Aragón & 8 & Aragón & 1,1 \\
\hline Melilla & 1 & Melilla & \\
\hline Total & 676 & Total España & 8,3 \\
\hline
\end{tabular}

Fuente: JEREZ DARIAS, L.M.; MARTÍN MARTÍN, V.O.; y PÉREZ GONZÁLEZ, R.

Aproximación a una geografía de la corrupción urbanística en España. Ería: Revista Cuatrimestral de Geografía [en línea]. Departamento de Geografía de la Universidad de Oviedo, 2012, no87, p.12. [Consulta: 21/04/2014]. Disponible en:

$<$ http://dialnet.unirioja.es/servlet/articulo?codigo $=4004228>$ 
Las conclusiones que refleja el susodicho estudio sobre el porqué de la proliferación de las prácticas corruptas en la administración local resultan especialmente interesantes. Por un lado se plantea la existencia de intereses por parte de los agentes económicos más poderosos que requerirían del beneplácito de las administraciones públicas; con el auge de la actividad urbanística aparece un ejemplo claro, en el que grandes promotoras (también constructores) veían cómo aparecían negocios en los que entraban en juego grandes sumas de dinero, y que en ocasiones se veían obstaculizados por el planeamiento urbanístico municipal; por requerir de alguna reclasificación de suelo, por ejemplo. De ese modo, era frecuente que se tratase de sobornar al político con competencias en la materia, cargos cuyas remuneraciones no destacan precisamente por abultadas y que por tanto pueden dar pie a vulnerabilidad de los representantes políticos ante las presiones de los agentes económicos; así lo corrobora que, según el estudio, hasta el $88 \%$ de los casos de corrupción estén relacionados de algún modo con el planeamiento o con la gestión y ordenación del suelo.

La segunda causa propuesta se podría derivar directamente de esta primera, ya que no es otra que la predisposición tanto de los partidos como de los funcionarios al soborno, alentado en buena medida por unos sueldos que no destacan precisamente por boyantes en la mayoría de los casos (sin que ello suponga una crítica a las cuantías que se cobran por parte de dichos cargos, que en la mayoría de los casos van simplemente acordes al volumen de trabajo que soportan). Por último, y probablemente sea uno de los factores más incomprensibles, está la propia naturaleza de la codificación jurídica a la que se someten estos casos. Con una permisividad en muchas ocasiones asfixiante hacia el uso indiscriminado del recurso, la falta de control o incluso la connivencia entre unos escalones y otros de la jerarquía administrativa (conviene rescatar la sospechosamente repetida coincidencia entre los partidos que sustentan gobiernos regionales y locales allí donde aflora la corrupción), la quizás excesiva libertad de los ayuntamientos a la hora de clasificar y calificar suelos, o el tan de actualidad abuso de la solicitud de indulto por parte de políticos ya juzgados y condenados, estrategia con la que en el peor de los casos se logra retrasar aun más una ya de por sí extenuante lentitud en la aplicación de justicia.

Por otro lado, dejando ya de lado la faceta de la corrupción urbanística, conviene incidir en la tercera de las burbujas que reventó junto con la financiera y la inmobiliaria, de consecuencias especialmente dramáticas en su faceta más humana. Se trata de la burbuja del empleo, cuya mejor expresión se encuentra en las palabras del Ministro de Trabajo (1996-1999), Javier Arenas, que como también recoge Mariano Guindal (2011, p.419) en su libro llegó a declarar que hacía falta traer legalmente a más de cincuenta mil personas a España porque faltaba mano de obra, claro reflejo del modelo económico diseñado por el Ministro de Economía Rodrigo Rato. En efecto España pasó a ser un país de inmigración cuando tradicionalmente lo había sido de emigración, con una importante bolsa de inmigración ilegal e irregular que se toleraba porque se les necesitaba para trabajar. Con el estallido de la burbuja inmobiliaria reventó también esta otra burbuja de empleo, cuyos efectos son de sobra conocidos en forma de empobrecimiento generalizado y migraciones de regreso en ocasiones planificadas con los países de destino (el caso paradigmático es el de Ecuador) como más visibles consecuencias. 


\section{El urbanismo como fenómeno económico: los reyes del ladrillo y los nuevos ricos. Consecuencias sociales de la burbuja y su estallido}

En definitiva, se pueden identificar dos perfiles en los agentes que participaron engordando la burbuja inmobiliaria. Por un lado aparecen los conocidos como Reyes del ladrillo (Guindal, 2011, p.416 y sigs.), una serie de empresarios que hicieron fortuna sabiendo aprovechar las oportunidades que planteaba la construcción, ya no sólo de viviendas a través de grandes promociones, sino también de la obra pública, con grandes estrategas de los concursos públicos que amasaron en muy pocos años enormes fortunas. Son fácilmente identificables nombres sobradamente conocidos, como las hermanas Koplowitz (FCC), Juan Abelló (Sacyr Vallehermoso) o la familia Del Pino (Ferrovial). Se trata de una nueva generación de empresarios que relevaron a los que se habían enriquecido durante la dictadura franquista con la industria, y que se erigían como auténticos genios de las concesiones, las contratas y las subvenciones, con una ambición que los llevaría a invertir en bolsa y tratar de controlar también a los grandes nombres de la banca y las energéticas. Quizás el nombre más conocido y que merece mención aparte sea el de Florentino Pérez, presidente de ACS y del Real Madrid C.F., y que resulta paradigmático por su mano para unir fútbol, política y negocios y consolidarse como uno de los empresarios con más poder en todos los sentidos. Especialmente revelador resulta el siguiente entrecomillado atribuido al periodista Juan Carlos Escudier que Mariano Guindal recoge en su libro El declive de los dioses:

"Jesús Gil decía que el palco del Real Madrid es como las cacerías de Franco, en las que había que estar aunque no te gustara la caza; en ese palco hay que estar aunque no te guste el fútbol. En la etapa de Zapatero algo menos, pero durante el Gobierno de Aznar prácticamente todo el Consejo de Ministros se sentaba allí. Ha hecho confluir los intereses del Real Madrid con ACS, convirtiendo el palco blanco en kilómetro cero de los negocios españoles. ”(Guindal, 2011, p. 475 y ss.).

El segundo de los perfiles clave en la configuración de la burbuja inmobiliaria española es sin duda el del nuevo-rico, rehuyendo de cualquier connotación negativa que se pueda derivar del término. Con la euforia económica y la sensación de estar subidos a un tren imparable se consolidó el perfil de la clase media con aspiraciones de llevar un nivel de vida frecuentemente excesivo para sus posibilidades económicas. Resulta especialmente ilustrativa, por mucho rechazo que genere entre según qué colectivos, la socorrida expresión de "haber vivido por encima de nuestras posibilidades". El efecto riqueza derivado del período de bonanza económica derivó en un endeudamiento a todas luces excesivo de los españoles, en una coyuntura en la que los propios bancos y cajas concedían créditos de forma masiva al tiempo que se financiaban con dinero del exterior. Ese círculo crediticio terminaría por estallar en 2007 al calor de la crisis financiera internacional.

Si bien se puede afirmar que el Gobierno de Aznar alentó el crecimiento de la burbuja inmobiliaria, igualmente cierto es que Gobierno de Zapatero no supo gestionar el problema ni antes ni después de que estallara. Son conocidas las palabras del Gobernador del Banco de España, Miguel Ángel Fernández Ordóñez, quien aseguraba que España contaba con el sistema financiero más saneado del mundo, premisa que no tardaron en adoptar tanto el ministro de economía de la época, Pedro Solbes, como el propio presidente Zapatero. Lo afirmaban porque en España no existían las hipotecas 
subprime que habían funcionado como cáncer del sistema estadounidense, pero lo que sí existía era un endeudamiento monumental al que había que unir la inexistencia de la figura de la dación de vivienda como sí existía en Estados Unidos. Ya en 2006, dos años después de la llegada al poder de Zapatero, la construcción empezaba a mostrar los primeros síntomas de debilidad materializados en las primeras dificultades para vender las viviendas. Se veía venir que la burbuja iba a reventar, pero hacerlo de forma controlada resultaba casi imposible dado que el sector copaba el 35\% de la actividad española, más cuando el turismo, erigido como la otra pata del sistema, empezaba a flaquear por la incipiente crisis en los países emisores. A todo ello cabía añadir una crisis de la deuda fruto de que España llevaba financiando su desarrollo con dinero prestado del exterior desde mediados del siglo XX, situación que se había agravado en los años 2000.

El resultado más visible de la crisis, además de los miles de nuevos desempleados, el frenazo del consumo y la crisis de la deuda soberana, se manifiesta a través de la enorme cantidad de viviendas que hoy salpican el territorio nacional sin inquilinos, algunas terminadas y conformando una auténtica invasión del antes medio rural, sobre todo en las cercanías a las grandes ciudades y en las proximidades al litoral, y otras como simples esqueletos de hormigón que con los años se han deteriorado hasta el punto de no soportar otro futuro que la demolición.

\section{LA POLÍTICA URBANÍSTICA RECIENTE EN CASTALLA}

Como ya se apuntaba con anterioridad, el modelo socioeconómico de Castalla durante los años de bonanza previos a la actual crisis podría identificarse como paradigmático de municipio rural que incorpora la construcción como bandera del dinamismo económico. No quiere con ello decir que Castalla se apoyase en los trabajos del sector primario, como bien queda demostrado en la figura 2, donde el volumen de empleados en el sector agrícola resulta cuando menos testimonial. Castalla en efecto es un municipio que, junto con sus vecinos Onil e Ibi, se ha apoyado en la industria para prosperar económicamente. Buena prueba de ello son los importantes polígonos industriales con que cuentan los tres municipios, en relación al tamaño de sus poblaciones. 


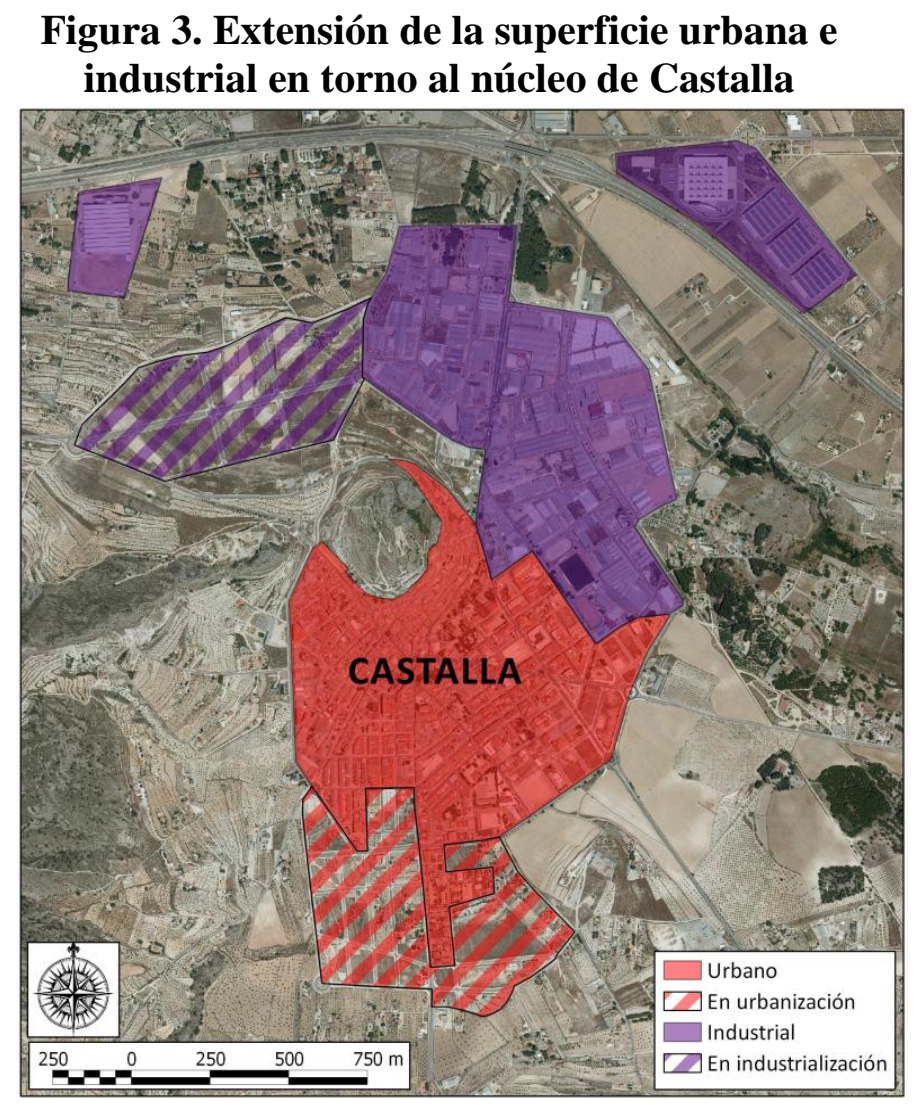

Fuente: PNOA. Elaboración propia

El crecimiento repentino del interés por urbanizar en Castalla responde claramente a la cercanía del municipio con el litoral valenciano y con la capital provincial. En efecto, volviendo al contexto español se detectaba cómo la mayor presión urbanística se producía en las provincias litorales y en las cercanías a grandes ciudades como pueda ser Madrid. En el caso de Castalla el interés de promotores y compradores por su suelo llega bastantes años después de que la fiebre urbanística hubiese alcanzado a los municipios litorales, cuando en muchos casos ya se habían colonizado estos últimos por completo. Con la saturación de la primera línea de costa el interés urbanístico remonta tierra adentro buscando terrenos todavía libres de urbanización por dos motivos principales: por un lado la menor demanda (en relación con el litoral) abarata sustancialmente los suelos, pese a que de todos modos éstos también habían sufrido los efectos de la revalorización artificial propia del boom; por otro lado, la menor congestión de viviendas ofrecía un valor paisajístico que ya no se encontraba en el litoral, absolutamente abarrotado de viviendas y con unos ritmos de vida urbanitas que no siempre respondían al ideal de tranquilidad que buscaban muchos de los nuevos residentes tanto extranjeros como nacionales.

En este sentido, la propia configuración física de la provincia de Alicante, predominantemente montañosa en su mitad norte, condicionaba y mucho este proceso. En un principio se plantea como un obstáculo, dado que el relieve aísla en muchos casos a los municipios interiores de la costa pese a distar en pocos kilómetros del litoral, pero por otro lado podría añadir un nuevo componente de atractivo al producto turístico y residencial si se presentaba como la perfecta combinación entre la montaña y el mar. Para ello evidentemente juegan un papel fundamental las infraestructuras de comunicaciones que logran acercar en un tiempo escaso medios tan distintos como el 
frenético litoral turístico alicantino y los tranquilos pueblos de la montaña. Es éste el factor principal que explica la llegada de nuevos residentes a Castalla y que justifica toda una política urbanística orientada a producir una oferta suficiente de vivienda que satisficiera la ingente demanda que se preveía, gran parte de la misma absolutamente ficticia.

La Hoya de Castalla está atravesada por la autovía A-7 o Autovía del Mediterráneo, que en su conjunto conecta Algeciras (Cádiz) con Barcelona y que a escala regional conecta Alicante con Valencia por Alcoy, una vía por tanto que se establece como columna vertebral del interior norte alicantino en lo que a infraestructuras de comunicaciones se refiere. Además, desde el año 2005 existe una autovía que conecta Castalla con Sax, y que comunica la autovía Alicante-Alcoy con el valle del Vinalopó. Más allá de las evidentes ventajas en el plano industrial que estas infraestructuras suponen, la consecuencia directa que se desprende es la conexión entre el congestionado litoral (sobre todo el cercano a la capital) y una subcomarca del interior que hasta los años 2000 estaba muy poco urbanizada, todo ello en menos de media hora en vehículo.

Dada la cercanía en tiempo respecto a la capital, Castalla y sus municipios vecinos no tardaron en ver llegar un flujo creciente de familias, por lo general jóvenes, que se establecían en estas localidades siguiendo el modelo de ciudad dormitorio sobradamente conocido en otros municipios de la provincia, como pueda ser San Vicente del Raspeig respecto de Alicante. La prueba más evidente se encuentra sin duda en el municipio de Tibi, el más pequeño de la Hoya de Castalla y que en 2013 apenas alcanzaba los 1.757 habitantes. Lo más llamativo es que en ese mismo año el $42,5 \%$ de sus habitantes $(747$ vecinos) vivían fuera del núcleo de Tibi, distribuidos en hasta cinco urbanizaciones además del poblamiento diseminado ${ }^{3}$. No es extraño que esto se dé así dado que Tibi es el primer municipio que se encuentra al subir desde Alicante hasta la Hoya de Castalla, lo que se ve acentuado por la propia pequeñez demográfica del municipio en cuyas condiciones, por regla general, las autoridades municipales tienden a fomentar la llegada de nuevos vecinos que engorden las listas del Padrón Municipal y que por tanto ofrezcan el mayor peso posible en lo que a habitantes se refiere para poder reclamar ante las autoridades regionales los servicios municipales correspondientes.

\section{LA URBANIZACIÓN "CASTALLA INTERNACIONAL": PRIMER GRAN PROYECTO URBANÍSTICO DE LA ÉPOCA EN CASTALLA}

\section{La política cortoplacista aplicada al urbanismo}

Sería en agosto de 1997 cuando se diera el primer paso para la construcción de una gran urbanización en el término municipal de Castalla, independiente del núcleo urbano tradicional. Desde un primer momento el equipo de gobierno mostró la máxima simpatía hacia el proyecto y dispuso todas las facilidades posibles para que la urbanización saliese adelante en los años siguientes. El entonces alcalde, el histórico dirigente del Partido Popular (que gobernó el municipio durante veinte años, de 1987 a 2007) Juan Rico Rico declaraba que con la construcción de Castalla Internacional no

\footnotetext{
${ }^{3}$ Nomenclátor: población del padrón continuo por unidad poblacional. Demografía y Población, Instituto Nacional de Estadística [en línea]. [Consulta: 23/04/2014]. Disponible en:

<http://www.ine.es/nomen2/index.do >
} 
sólo se "podría impulsar el turismo interior" sino que además "podría convertirse en una fuente de riqueza alternativa para el municipio". 4

Es frecuente que los dirigentes políticos de toda índole y categoría apuesten por la creación de empleo y riqueza a la hora de legitimar proyectos urbanísticos en un contexto de auge del turismo y del residencialismo. Muchas veces cala la opinión de que ambas modalidades repercuten positivamente en la economía local, aunque desde luego son muchas las matizaciones que merece dicha afirmación. Como bien explica el Catedrático de Análisis Geográfico Regional en la Universidad de Alicante, José Fernando Vera Rebollo, la promoción del turismo de base hotelera o similar, es decir, aquél en el que el promotor de la actividad no construye y vende, sino que construye y gestiona un equipamiento a lo largo de un determinado tiempo para extraer de él un beneficio económico, sí puede repercutir en el empleo local y por tanto en la economía del lugar de una forma más o menos continuada, dado que se crean puestos de trabajo asociados al servicio que en los equipamientos se presta, el visitante tiende a consumir en establecimientos hosteleros y en definitiva se crea un dinamismo económico basado en el consumo del foráneo; todo ello va acompañado de una mayor implicación por parte del empresario promotor con la realidad local dado que su beneficio depende en buena medida del mantenimiento e incluso mejora de los activos que un lugar ofrezca como atractivos turísticos. En cambio, el residencialismo se basa en la construcción de nuevas viviendas, y por tanto su dinámica es bien distinta. El empresario promotor tiene como objetivo la construcción y venta del producto inmobiliario, y completado ese corto ciclo su compromiso con la realidad local desaparece; el adquiriente, por su parte, pasa a ser vecino y como tal generará el consumo propio de todo residente y al mismo tiempo ocasionará los gastos propios de todo vecino. En definitiva, se trata de una dinámica cuya repercusión económica es cuando menos cortoplacista, en el momento de comprar la vivienda y a la hora de equiparla, ya que a partir de ese momento se convierte en un residente más que no sólo genera ingresos para la economía local sino también gastos por requerir de los servicios y equipamientos cotidianos.

Probablemente no resulte nada descabellado vincular este tipo de fenómenos de repercusiones económicas muy cortoplacistas con la propia dinámica política y la concepción de la misma que se ha generalizado en la todavía joven democracia española. Y es que en un sistema político en el que el dirigente-gestor rinde cuentas cada cuatro años la tentación de gobernar pensando exclusivamente en la obtención de resultados en ese corto periodo de tiempo lleva a que las medidas estructurales brillen por su ausencia, incluso en el caso de aquéllas que se presentan a la opinión pública como tales y que con el paso del tiempo acaban demostrándose tan coyunturales como las otras al ser reemplazadas con franca prontitud; es el caso de las Leyes Orgánicas de Educación, por poner un ejemplo paradigmático fuera del ámbito aquí tratado. Sería inexacto, sin embargo, atribuir estas deficiencias al propio sistema democrático, ya que tiene que ver más bien con la concepción que una sociedad tenga de él y lo arraigado que esté en una determinada escala de valores el sentido de la responsabilidad, dado que en otros sistemas democráticos como el japonés o incluso los escandinavos el sentido de la política a medio y largo plazo funciona con relativa normalidad.

\footnotetext{
${ }^{4}$ SERRANO, C. La promotora de Castalla Internacional quiebra y deja 350 viviendas sin terminar. Diario Información [en línea]. 29/12/2011. [Consulta: 22/05/2014] Disponible en: <http://www.diarioinformacion.com/alcoy/2011/12/29/promotora-castalla-internacional-quiebra-deja350-viviendas-terminar/1206440.html >
} 
Volviendo al caso de Castalla Internacional, conviene recordar que no se pretende tampoco en este trabajo realizar una investigación pormenorizada de un proyecto urbanístico cuyas luces y sombras destacan por un claro desequilibrio a favor de estas últimas, y que se extienden irremediablemente a la gestión urbanística de los equipos de gobierno que dirigieron Castalla durante la década de los años 2000 hasta el pinchazo de la burbuja inmobiliaria en España, todos ellos en manos del Partido Popular.

\section{Figura 4. Vista cenital de la urbanización "Castalla Internacional}

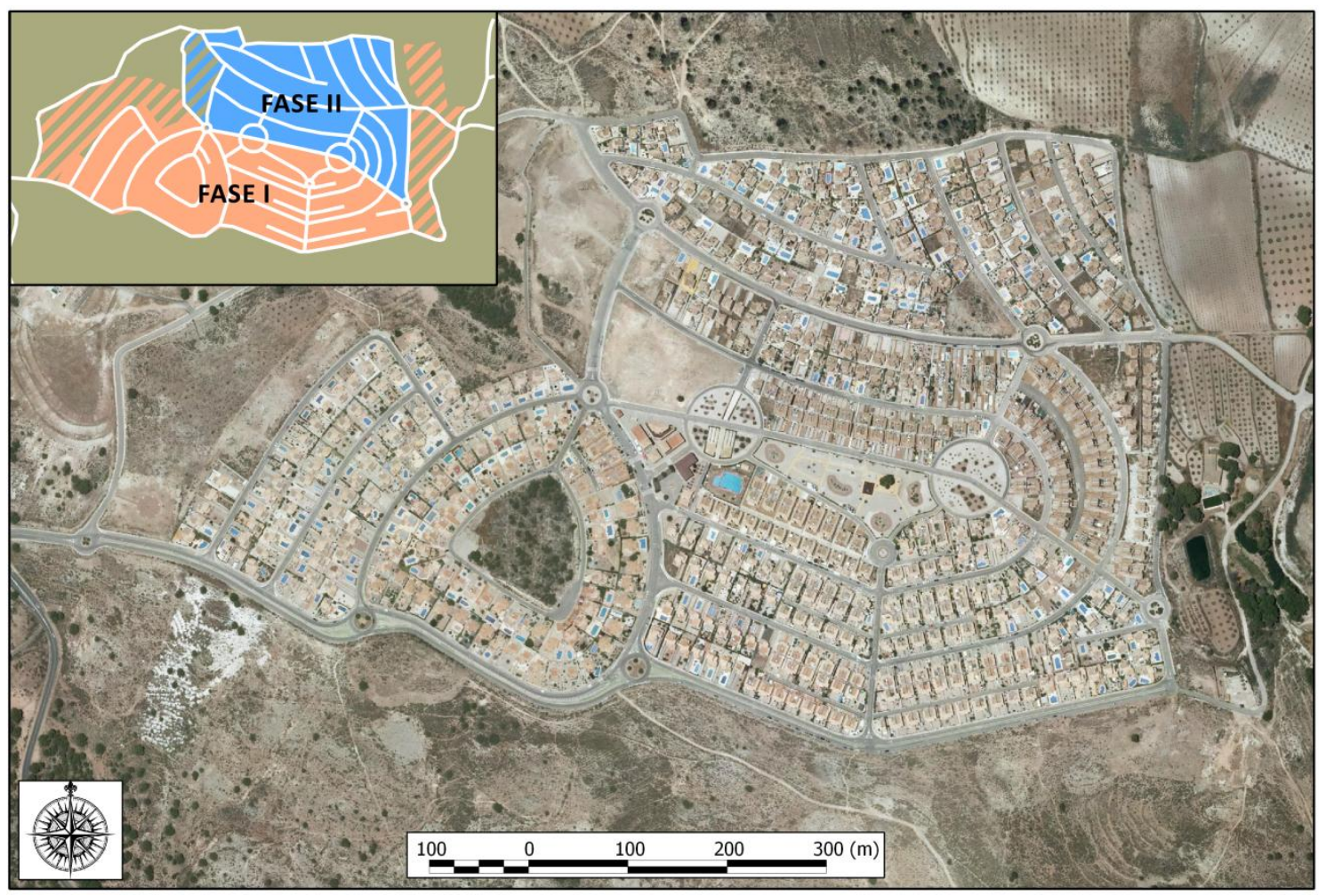

Fuente: PNOA máxima actualidad (2012) y Plan General del Término Municipal de Castalla (2002). Elaboración propia.

El Plan General del Término Municipal de Castalla que se aprobó en julio de 2002 (en adelante, PG 2002) incluía un incremento considerable de los terrenos considerados como urbanizables, los criterios que se utilizaron para lo cual merecerían pormenorizado y crítico estudio todavía a día de hoy dado que más de diez años después siguen observándose a simple vista en el territorio las nefastas consecuencias de algunas de aquellas decisiones tomadas en pleno frenesí de la burbuja inmobiliaria, fervor que parece que en muchos casos debió nublar los juicios de bastantes dirigentes políticos del ámbito municipal a lo largo y ancho del país. Para Castalla Internacional, el PG 2002 preveía hasta 28'8 hectáreas de terreno en una zona conocida como "Els Campellos", nombre que heredó la urbanización junto con el otro, mucho más utilizado por pintoresco, incluso rayano en lo estrafalario. En ese terreno se preveía una capacidad de hasta 570 viviendas unifamiliares, todo en un proyecto que en principio debía tener 350 viviendas y que, culminadas éstas, se amplió a una segunda fase que resultó ser la que mayores problemas ha acabado trayendo. 


\section{Más sombras que luces: intereses contrapuestos, rencillas personales y extrañezas de todo tipo. Un clima político insoportable}

Quizás uno de los episodios más sonados de la accidentada tramitación del proyecto sea el que se produjo en octubre de 2006. En esas fechas se publicaba en el Boletín Oficial de la Provincia de Alicante ${ }^{5}$ el acuerdo de la Comisión Territorial de Urbanismo de mayo de ese año por el que se formalizaba la cédula de urbanización de la citada Fase II del proyecto. Hasta aquí nada extraño, si no fuera porque tal y como recogía la prensa comarcal había ya más de 400 chalets construidos. El incidente se tradujo en un cruce de acusaciones entre populares y socialistas que se extrapoló también al ámbito regional cuando desde el PSPV-PSOE se pidió la cesión del entonces Conseller de Territorio y Vivienda, Esteban González Pons "por los nuevos pasos dados para legalizar una urbanización de 450 viviendas en Castalla a pesar de que no cumple con la legislación vigente, carece de autorización de la Confederación Hidrográfica, vierte aguas residuales y ha sido construida al margen de los permisos municipales, sin que el Ayuntamiento haya tratado de impedirlo" . Como era de esperar desde el Ayuntamiento se negaron las acusaciones vertidas por el PSPV-PSOE y el asunto no tardó en quedar obsoleto dentro de un clima político invadido por el constante cruce de acusaciones entre PP y PSOE a colación de cualquier particular.

En ese acuerdo de la Comisión Territorial de Urbanismo se hacía constar una serie de deficiencias que debían subsanarse "previamente a la ejecución del sector", y por tanto a las que se subordinaba la estimación como favorable de la Declaración de Impacto Ambiental. Entre esas deficiencias destacan dos por su especial repercusión ambiental: por un lado la ampliación del tratamiento de la depuradora de aguas residuales para un caudal de $800 \mathrm{~m}^{3} /$ día y 4.000 habitantes, todo ello con una calidad del agua adaptada a los parámetros establecidos y con la preparación de un protocolo de actuación para casos de fallo en el sistema de depuración que evitara contaminaciones; por otro lado, destaca también la clausura de un vertedero cercano y la obtención de las autorizaciones preceptivas por parte de la Dirección General de la Calidad Ambiental.

Cabe pensar que algo en la tramitación no se llevó a cabo con toda la corrección que cabría exigir si se permitió que se construyeran más de cuatrocientas viviendas sin haberse resuelto el acuerdo de la Comisión Territorial de Urbanismo, acuerdo además que estaba especificando deficiencias que atender a las que supeditaba la resolución favorable. La sensación que de ello se puede desprender es que en realidad lo que se estaba haciendo era legalizar a posteriori una serie de actuaciones llevadas a cabo sin las pertinentes autorizaciones administrativas.

En el año 2009 volvió al epicentro de la atención mediática local el asunto por una querella que presentó el Partido Popular de Castalla contra el alcalde de su propio

\footnotetext{
${ }^{5}$ Boletín Oficial de la Provincia de Alicante, n²50, 31/10/ 2006 [En línea]; pág.14 y sigs. [Consulta: 21/05/2014]. Disponible en: 〈http://www.dip-alicante.es/bop2/pdftotal/2006/10/31-10-06.pdf >

${ }^{6}$ ESCAPARATEDIGITAL.COM. La Conselleria de Territorio y Vivienda legaliza la segunda fase de Castalla Internacional cuando ya hay más de 400 chalets construidos. [En línea]. 06/11/2006 [Consulta: 21/05/2014]. Disponible en:

<http://www.escaparatedigital.com/noticia_detalle.php?id=ufI8r17857151xmcDWCldMg5br7CFv510Kaw $\underline{\text { T3innfwp\&iVR=4 }>}$
} 
partido acusándolo de otorgar licencias de obra a cambio de filiaciones al $\mathrm{PP}^{7}$. Este sorprendente episodio sólo se entiende si se contextualiza en un momento de especial tensión dentro de la agrupación conservadora previo a las elecciones internas a la Presidencia de la Asamblea Local Popular. El Ayuntamiento de Castalla estuvo gobernado por el PP de forma ininterrumpida desde 1987 hasta 2011, ocupando la alcaldía durante los veinte primeros años el histórico dirigente popular Juan Rico Rico. Cuando en 2007 éste abandonó la primera línea política, lo sustituyó al frente del PP local y luego de la alcaldía el que había sido concejal de sanidad en la última legislatura de Rico, José Luis Prats, médico de profesión y una de las personas más carismáticas de la sociedad castallense. Pronto aparecieron las discrepancias internas en el partido, ya que un sector nada despreciable de la agrupación se mostraba contrario a la línea emprendida por Prats y pretendía que no repitiese como candidato a las elecciones municipales de 2011. Sin embargo la dirección regional del PP dio su apoyo a Prats que, amparado por una mayoría absoluta en 2007, se volvió a presentar en 2011. Las desavenencias dentro del partido terminaron con una escisión liderada desde el segundo puesto de la lista electoral por Juan Antonio Rico, hijo del histórico alcalde Juan Rico Rico, y que se hizo llamar UCiD.

El último pleno de la legislatura 2007-2011 resulta clave en el desarrollo de los acontecimientos en Castalla Internacional. El todavía alcalde y candidato a la reelección, José Luis Prats, lograba que el pleno aprobase la devolución a la empresa constructora de la urbanización, Marsadi S.A., de 1'5 millones de euros de los 2'8 millones que formaban el aval depositado ante el Ayuntamiento. Las obras en la urbanización no estaban terminadas y unas semanas después la empresa constructora declaró concurso de acreedores.

Los resultados de las elecciones de 2011 contagiaron al clima político del Ayuntamiento las tensiones que se venían arrastrando en el Partido Popular. El PP perdió la mayoría absoluta que llevaba revalidando desde hacía años, por un solo concejal. El nuevo gobierno terminó formado por un tripartito absolutamente antinatura formado por PSPV-PSOE, Bloc-Compromís, y la escisión de los conservadores, UCiD. Curiosamente la cartera de urbanismo fue a parar a Juan Antonio Rico, constructor de profesión e hijo como ya se ha apuntado del alcalde que dirigió el municipio durante la burbuja inmobiliaria.

\footnotetext{
${ }^{7}$ EUROPAPRESS. Militantes del PP de Castalla (Alicante) denuncian por cohecho y apropiación indebida a su propio alcalde. [en línea]. 19/08/2009. [Consulta: 21/05/2014]. Disponible en: <http://www.europapress.es/nacional/noticia-militantes-pp-castalla-alicante-denuncian-cohechoapropiacion-indebida-propio-alcalde-20090819184918.html >
} 


\section{Figura 5: Resultados de las elecciones municipales de 2011 en Castalla}

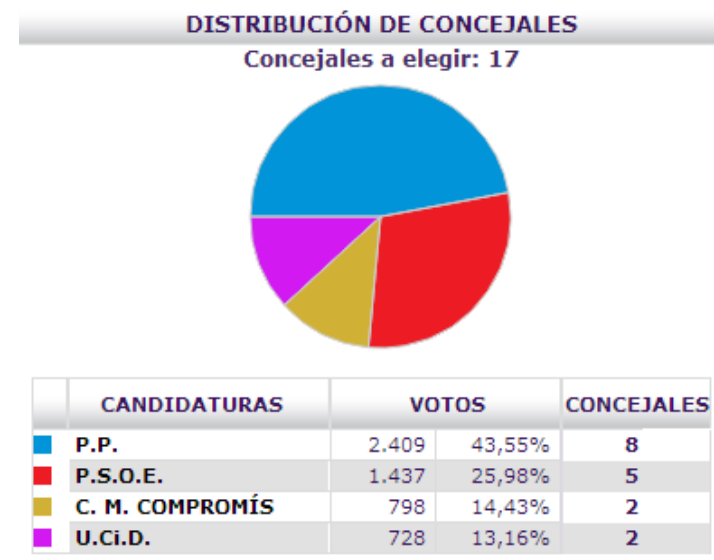

Fuente: Ministerio del Interior, Gobierno de España.

Durante esos tres primeros años de legislatura el clima político estuvo regido por la tensión heredada de los resultados electorales, con dimisiones a ambos lados del arco, denuncias por mala praxis política, y escándalos varios por gastos desorbitados o injustificados. Tras unos meses en el tripartito, UCiD dejó el equipo de gobierno en lo que muchos interpretaron como un primer paso hacia la reconciliación de los conservadores. En efecto así fue: en mayo de 2013, dos años después de las elecciones, PP y UCiD presentaban una moción de censura al gobierno bipartito, que se mantenía en el poder a duras penas en una estrepitosa minoría de seis concejales de diecisiete tras la salida de UCiD y el abandono del grupo municipal socialista por parte de uno de sus concejales para integrarse en el de no-adscritos. El acuerdo entre PP y UCiD fue posible sólo tras la renuncia al acta de concejal del hasta entonces líder del grupo municipal del PP y exalcalde de Castalla, José Luis Prats, renuncia que por otro lado constituía una de las principales exigencias de UCiD para devolver el poder al PP. La alcaldía quedó en manos del que había sido número dos de la lista de los populares en las elecciones de 2011, Juan Antonio Candela, mientras que la cartera de urbanismo, curiosamente, volvía a recaer en el edil Juan Antonio Rico, acompañada esta vez de las competencias en obras públicas.

El proyecto de Castalla Internacional, como buena parte de la gestión urbanística de esos años, ha estado bajo la sombra de la sospecha en más de una ocasión. Según recogía el diario $E l M_{u n d o}{ }^{8}$ en un mapa de la corrupción urbanística el propio alcalde popular Juan Rico Rico habría reconocido la construcción durante su extenso mandato de más de mil viviendas no autorizadas. En octubre de 2012 la prensa provincial anunciaba que la Fiscalía estaría investigando la devolución del aval por parte de la corporación de José Luis Prats ${ }^{9}$. Con todo ello no es raro que entre la opinión pública castallense haya aparecido recurrentemente la impresión de corrupción generalizada,

\footnotetext{
${ }^{8}$ EL MUNDO. Ladrillo a ladrillo, el mapa de la especulación. [En línea]. Noviembre de 2006. [Consulta: 21/05/2014]. Disponible en: <http://www.elmundo.es/especiales/2006/11/espana/corrupcion_urbanistica/sospechosos.html>

${ }^{9}$ SERRANO, C. La fiscalía investiga la devolución del aval de Castalla Internacional. En: Información [en línea]. 19/10/2012 [Consulta: 21/05/2014]. Disponible en: <http://www.diarioinformacion.com/alcoy/2012/10/19/fiscalia-investiga-devolucion-aval-castallainternacional/1306285.html>
} 
frecuentemente acompañada de la impotencia que provoca la sensación de impunidad de aquéllos sobre los que reiteradamente sobrevuelan asuntos turbios y sombríos. La certeza sobre hasta qué punto esas impresiones tienen razón de ser o no debe emanar en todo caso de los juzgados, pero no por ello se ha de restar importancia al efecto que sobre los ciudadanos provocan, y que cuando menos acaba materializándose en un clima de crispación generalizada, en desafección hacia la política, y sobre todo en auténtico hastío cuando se comprueba que al final asuntos tan serios como éstos acaban utilizándose como arma arrojadiza entre los partidos políticos con los que fomentar el infructífero y descorazonador "y tú más".

Un primer paso hacia la pública información de la situación de la urbanización en la actualidad se dio en abril de 2014, cuando se celebró una reunión entre el actual alcalde de Castalla, Juan Antonio Candela (PP) y el Grupo de Trabajo de UPyD en Castalla a petición de este último, tras registrar en el Ayuntamiento una batería de preguntas ${ }^{10}$ surgidas de una reunión previa con vecinos de la urbanización. Tras la reunión con el alcalde, el Grupo de Trabajo de UPyD en Castalla publicaba las respuestas obtenidas así como algunas reflexiones al respecto ${ }^{11}$.

Destacan varias respuestas por sorprendentes por parte de la corporación. En primer lugar, el alcalde informaba de que de las dos fases con que cuenta la urbanización sólo la primera está entregada y debidamente recepcionada por el Ayuntamiento. Por tanto, la Fase II no estaría en condiciones de ser habitada, algo que choca con lo que explicaron los residentes, que aseguran que en ella sí han vivido vecinos en los últimos años. En lo referente al aval, el alcalde informó, según lo expuesto por el Grupo de Trabajo de UPyD en Castalla, de que los 850.000€ que no se devolvieron de la fianza inicial no cubren con los gastos de urbanización pendientes, por lo que sorprende escandalosamente que se devolvieran a la empresa los 1'5 millones de euros restantes. Para más inri, al preguntar sobre el informe técnico que justificaba la devolución, el alcalde reconoció que dicho informe existía pero no había sido emitido por los técnicos funcionarios municipales, sino por técnicos externos contratados a tal efecto, lo que no hace sino acrecentar las sospechas de irregularidad.

\section{LA DESASTROSA Y DESPROPORCIONADA AMPLIACIÓN DEL NÚCLEO DE CASTALLA}

Aunque sí es el más sonado, la urbanización Castalla Internacional no es el único punto turbio de la gestión urbanística municipal en los últimos años. La propia apuesta por la construcción que se desprende de lo reflejado en el PG 2002 es clara a este respecto. Al mismo tiempo que se estaban clasificando como urbanizables $28^{\prime} 8$ hectáreas en Castalla Internacional con capacidad para 570 viviendas, se planificaba la expansión al sur del propio núcleo de Castalla con otras 57'84 hectáreas clasificadas como urbanizables, con capacidad según el PG 2002 para 3.277 viviendas más. Así, durante los años de la

\footnotetext{
${ }^{10}$ GRUPO DE TRABAJO DE UPyD EN CASTALLA. UPyD pide información al Ayuntamiento tras la reunión con vecinos de Castalla Internacional. [En línea]. 25/03/2014 [Consulta: 21/05/2014]. Disponible en: <http://castallainternational.blogspot.com.es/2014/04/reunion-con-el-alcalde-de-castallapara.html>

${ }^{11}$ GRUPO DE TRABAJO DE UPyD EN CASTALLA. Primeras conclusiones sobre Castalla Internacional. [En línea]. 01/05/2014 [Consulta: 21/05/2014]. Disponible en: <http://castallainternational.blogspot.com.es/2014/05/primeras-conclusiones-sobre-castalla.html >
} 
burbuja se abrieron nuevas calles y se preparó la ampliación del núcleo delimitando las parcelas, instalando saneamiento, alumbrado público y demás equipamientos, y construyendo tres grandes parques que debían servir como zonas verdes para estos nuevos "barrios" (término muy poco utilizados en poblaciones pequeñas como Castalla). Los terrenos afectados habían estado hasta el momento dedicados a la agricultura, fundamentalmente de almendro y con presencia también de olivos, salpicados por algunas viviendas familiares aisladas, tema éste nuclear en este trabajo y en el que se profundizará más adelante. La paradoja se produjo al reventar la burbuja inmobiliaria cuando todavía los proyectos que se habían proyectado en estos terrenos estaban en una fase muy inicial que en la mayoría de los casos no había llegado a materializarse en la puesta de un solo ladrillo sobre el suelo.

\section{Figura 6. Ampliación al sur del núcleo urbano de Castalla}

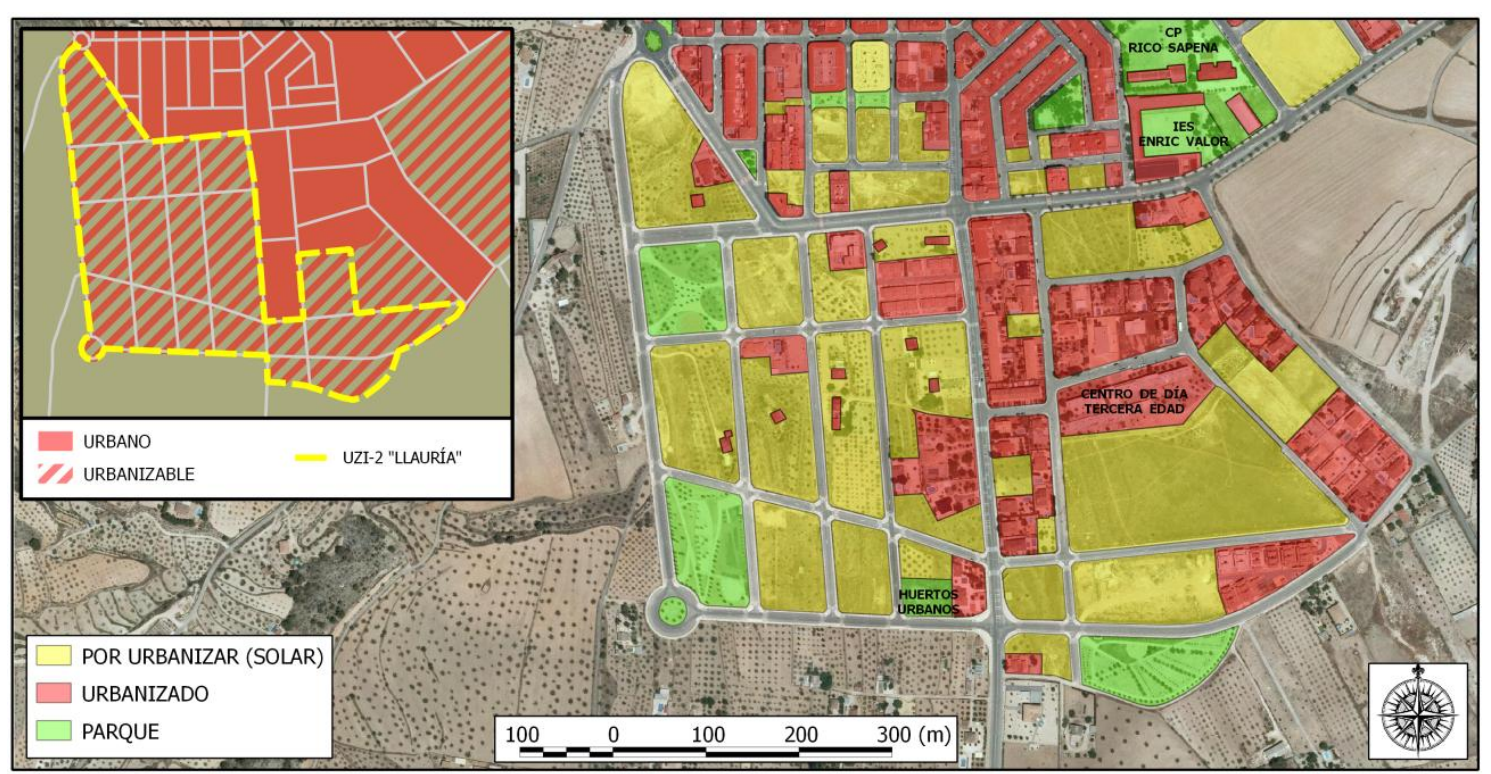

Fuente: PGOU 2002 y PNOA. Elaboración propia.

La escena que muestra el lugar en la actualidad es absolutamente desoladora. Muchas de las parcelas ni siquiera llegaron a perder su uso agrícola previo, por lo que aparecen en la actualidad bancales ocupando lo que deberían ser manzanas entre calles y calles. Los equipamientos se han deteriorado hasta puntos insospechados, sobre todo en lo que se refiere a la iluminación de los tres grandes parques que se construyeron, absolutamente arrasados por un vandalismo que cobra aquí tintes especialmente destacables por la situación de aislamiento respecto al resto del núcleo. Tanto es así que estos parques se conocen popularmente entre la juventud castallense como "el botellódromo" dado que se convierten en punto de encuentro de los jóvenes en las noches de los fines de semana.

Los pocos proyectos inmobiliarios que sí llegaron a emprenderse aparecen hoy en condiciones por lo general de auténtico abandono. No faltan ejemplos de viviendas a medio construir por quiebra de las promotoras; en otros casos los paquetes de viviendas quedaron a medio terminar, por lo que las primeras familias que se instalaron conviven con esqueletos de hormigón y aislados del resto del núcleo urbano. En el peor de los casos los precios de las viviendas incluían dotaciones para la comunidad, como puedan ser servicios de piscina o de seguridad para el conjunto, que obviamente no se pusieron en marcha al no venderse la mayoría de las viviendas. Es frecuente que las 
construcciones más avanzadas hayan sufrido saqueos, especialmente notables en lo que a sustracción de metal se refiere.

Fotografías 1 y 2: Parcela de almendros enclaustrada entre las calles proyectadas al sur de la ciudad, perfectamente señalizadas para tráfico urbano y con amplias aceras que apenas ven transeúntes (izquierda). Promoción de viviendas unifamiliares para rentas medias-altas a medio terminar, algunas ya habitadas y otras apenas con la estructura de hormigón (derecha)
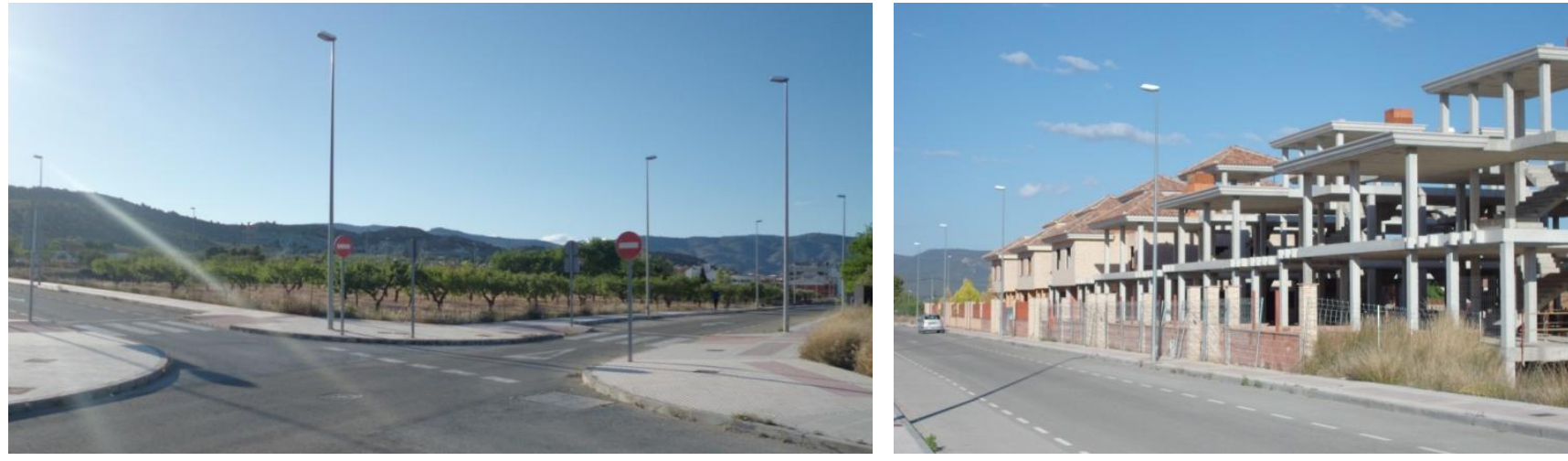

Autor: Sergi Esteve Rico (mayo de 2014)

\section{El paralelo derroche en obra pública de dudosa necesidad}

A esa política urbanística desmesurada cabe añadir una política de obra pública basada también en las grandes inversiones. Curiosamente el periodo con mayor puesta en marcha de este tipo de actuaciones coincide con la última legislatura que fue gobernada íntegramente por el Partido Popular con mayoría absoluta (2007-2011); prueba de ello es una revista propagandística que el propio PP distribuyó por todos los hogares de Castalla durante la campaña electoral previa a las elecciones de 2011, en la que se repasaba un buen número de actuaciones municipales llevadas a cabo en la legislatura que terminaba. Dando por buenos esos datos y echando mano de calculadora, el resultado es de $8.379 .262^{\prime} 74 €^{12}$ invertidos sólo en nuevas infraestructuras y equipamientos, y en acondicionamiento de otros anteriores. De esa cantidad, que el Partido Popular reflejó en actuaciones clasificadas en ocho apartados distintos, destaca el referido estrictamente a urbanismo e infraestructuras (sin contar equipamientos deportivos, educativos, etc.), que suma hasta 3.298.870'09€, y de los cuales 1.629 .506 ' $85 €$ corresponden a una única actuación (aunque en el folleto aparezca fraccionada en varias) llevada a cabo en la periferia del centro histórico y mediante la cual se repavimentaron varias calles que a priori no mostraban grandes deficiencias de estado, y se remodelaron hasta tres parques distintos, con bastante poca fortuna, dado que en uno de ellos se instaló una vistosa fuente de diseño que tuvo que ser remodelada pocos días después de su inauguración por acumular enormes cantidades de suciedad, y en el otro la pavimentación afectaba a un tramo del recorrido de los festejos de "la Vaca" (similar a los "Bous al Carrer") e introducía desniveles en los contactos de unas calles con otras que ponían en riesgo la integridad física de los participantes en el festejo.

\footnotetext{
${ }^{12}$ Supone una cifra considerable dado que, a modo orientativo, el capítulo de ingresos de los presupuestos municipales entre 2007 y 2011 fue, de media, de 7.831.612€, con un mínimo en 2007 (6.715.000€) y un máximo en 2009 (8.446.000€). Fuente: Presupuesto municipal de Castalla (1984-2014). Unidad de documentación de la Diputación de Alicante [En línea]. [Consulta: 17/05/2014]. Disponible en: <http://www.dip-alicante.es/documentacion/presupuesto.asp?municipio=53 $>$
} 
Se trata de una política de prioridades francamente curiosa, dado que al mismo tiempo que se invertían millones de euros en nuevos equipamientos e infraestructuras (muchas de las cuales, por cierto, se inauguraron en los meses previos a las elecciones de 2011) desde finales de 2009 el centro histórico de Castalla vivía una situación de absoluto abandono, con varias viviendas derrumbadas como consecuencia de unos episodios de lluvias continuadas que se sucedieron precisamente durante ese otoño de 2009 . Y es que la actitud de las sucesivas corporaciones municipales para con el centro histórico de Castalla ha sido la de favorecer el traslado de las familias que vivían en casas deterioradas a pisos ubicados en la periferia del núcleo, llevando así a una situación cada vez más grave de abandono y deterioro del corazón del municipio. El Ayuntamiento, escudado en la responsabilidad de los propietarios de las viviendas afectadas (algunas de ellas en manos de entidades bancarias a raíz de los impagos a los que muchas familias de pocos recursos se vieron abocadas con la crisis económica) tardó casi cinco años simplemente en desescombrar la zona, actuación tras la cual existen sospechas por parte de los vecinos de que puede haber un proyecto de cirugía urbana que rompería con la trama original de una parte del centro histórico y revalorizaría las parcelas adyacentes ${ }^{13}$.

\section{El parche de los huertos urbanos}

Antes de cerrar este apartado resulta interesante echar un vistazo a una iniciativa de la Concejalía de Desarrollo Local, cuyo responsable lo es también de Agricultura entre otras varias materias. Se trata de unos huertos urbanos impulsados por el Ayuntamiento en una de las parcelas, convenientemente adquirida por el consistorio, de las que quedaron definidas en la última ampliación del núcleo urbano de Castalla a la que se acaba de hacer referencia, y que por el pinchazo de la burbuja inmobiliaria quedó en la paradójica situación, como la mayoría de sus vecinas, de seguir utilizándose para explotación rural pese a estar delimitada por calles perfectamente equipadas.

Del pliego de condiciones se desprenden los trazos generales que esbozan la idea. Se trata de unas pequeñas parcelas cuyo uso se autoriza por un año prorrogable a un segundo, y en la que se permite el cultivo de productos para consumo humano y jardinería siguiendo los patrones de la agricultura ecológica. De los criterios de baremación se desprende la preferencia de los colectivos más afectados por la crisis, dado que se considera positivamente la situación de desempleo con atención a la renta, la existencia de familiares a cargo, la discapacidad y el riesgo de exclusión social vinculado a una situación de desempleo de larga duración. Además, está pensado para autoconsumo de quienes produzcan en el huerto, ya que no sólo se prohíbe explícitamente la comercialización de los productos, sino que además se considera infracción muy grave con sanciones que pueden llegar hasta los $3.000 €$.

En principio es un proyecto que por la función social que cumple parece desmerecer cualquier crítica que sobre él se pudiese verter. Obviando las opiniones que pueda tener quien escribe sobre la idoneidad del lugar elegido para su instalación por la dudosa calidad de la tierra, sí existen dos circunstancias que rodean los huertos urbanos que

${ }^{13}$ Reflexiones planteadas en las reuniones que la asociación "Veïns i Amics del Centre Històric de Castalla" mantuvo durante la primavera de 2014 con el Grupo de Trabajo de UPyD en Castalla, entre otros grupos políticos de la oposición castallense. 
merecen reflexión. Por un lado, tomando perspectiva temporal y viendo lo que se ha hecho por parte del Ayuntamiento en la zona, es inevitable encontrar paradójico que unos terrenos que originalmente tenían uso agrícola se reclasificasen como urbanizables con la idea de desarrollar en ellos un fuerte desarrollo inmobiliario, y que finalmente cuando la planificación de aquella expansión urbana se ha demostrado absolutamente innecesaria y ha traído los desastrosos efectos que ha traído se trate de recuperar el carácter agrícola del lugar mediante una testimonial parcela dedicada a la instalación de huertos urbanos. Cuesta evitar plantearse la pregunta de si no hubiese tenido más sentido respetar el carácter agrícola de aquellos terrenos desde un principio y no apostar ahora por proyectos absolutamente anecdóticos y no carentes de un cierto regusto propagandístico ${ }^{14}$ como son los huertos urbanos, cuyo éxito está todavía por demostrar.

Otra de las circunstancias que lleva a criticar la apuesta por los huertos urbanos es la existencia de un proyecto similar anterior que sigue desarrollándose hoy en día por parte de una asociación. Se trata del colectivo Imaginando, con varios ámbitos de actuación entre los que destaca para lo aquí expuesto el proyecto Imaginando Rural. En su blog ${ }^{15}$ se definen como un colectivo que busca el desarrollo social y económico del municipio y la comarca y la conservación del medio ambiente, mediante la "ocupación agrícola y la recuperación de cultivos". Por tanto son hasta cuatro las facetas que abarcan: lo económico, lo social, lo ambiental y lo cultural o patrimonial. El funcionamiento gira en torno a la cesión altruista de tierras (de su uso, no de su propiedad, tal y como ocurría con los huertos urbanos municipales) por parte de propietarios que libremente tengan a bien colaborar de esta manera; el perfil de quien cede el uso de las tierras suele ser el de propietario que cuenta con parcelas que no trabaja, frecuentemente heredadas. Una directiva que coordina y organiza el funcionamiento ofrece la posibilidad de poner en cultivo esas tierras fundamentalmente a desempleados, que pueden destinar esa producción al autoabastecimiento, y al mismo tiempo otras parcelas se dedican a investigación con plantas aromáticas y medicinales recuperando una tradición y preservándola del peligro de desaparición.

Según se expone en la presentación del proyecto en su blog ${ }^{16}$, se juega con tres perspectivas: a corto plazo se pretende el autoabastecimiento de quienes cultivan; a medio plazo se pretende la comercialización de excedentes (terminantemente prohibida en el caso de los huertos municipales), con lo que se toca también la vertiente económica; a largo plazo se busca la producción selectiva de productos de calidad. Por otra parte, desde la óptica empresarial se trata de dar un impulso a los futuros investigadores y emprendedores en el ámbito rural que a medio plazo conlleve la creación de sociedades cooperativas o sociedades limitadas, una forma por tanto de

\footnotetext{
${ }^{14}$ Basta con recuperar el vídeo que la empresa privada de televisión local Movitel S.A. grabó del día de la inauguración (26/11/2013), a la que asistieron tanto el concejal en cuestión, Ramiro Prats, como el alcalde de Castalla, José Antonio Candela, como el diputado en la Diputación de Alicante Alejandro Morant, y en la que no se escatimó en todo tipo de parafernalia que engalanase la inauguración de lo que no dejaba de ser un huerto, con atril para los discursos, banderas, cinta inaugural, placa que descubrir, alfombra roja y bendición del párroco incluidas.

Vídeo disponible en: 〈http://www.youtube.com/watch?v=P0_t0yvHcB4> [consulta: 21/05/2014]

${ }^{15}<$ http://imaginando.org/> [Consulta: 21/05/2014]

${ }^{16}$ ASOCIACIÓN IMAGINANDO. Presentación del Programa de Ocupación Agrícola y Recuperación de Cultivos. [En línea] 05/07/2012 [Consulta: 21/05/2014]. Disponible en: <http://imaginando.org/imaginando-rural/presentacion-del-programa-de-ocupacion-agricola-yrecuperacion-de-cultivos/>
} 
fomentar la recuperación de las actividades agrícolas en su vertiente económica, desde la humilde contribución que se pueda hacer desde esta asociación.

Es sin duda un proyecto que merece un estudio mucho más amplio y concienzudo que la somera presentación que se pretendía hacer aquí, dado que no sólo puede ser una forma de fomentar el necesario impulso a lo agrícola en los municipios en los que el tirón industrial y de los servicios ha sido tan fuerte que casi ha condenado a la agricultura al abandono. Al mismo tiempo, por sus características, parece razonable el estudio de las posibilidades de impulsar proyectos similares en otros municipios cercanos o no tan cercanos.

\section{EL POBLAMIENTO DISEMINADO EN EL TÉRMINO MUNICIPAL DE CASTALLA: UN PROBLEMA MUCHO MÁS GRAVE DE LO QUE APARENTA}

El fenómeno qué mayor interés suscita a los efectos planteados en este artículo es el de la eclosión del poblamiento diseminado por todo el término de Castalla. Cabe apuntar antes de proceder a cualquier análisis al respecto, por somero que éste fuera, que no es intención de este artículo realizar un estudio jurídico de las viviendas dispersas que existen en el término municipal de Castalla. Vaya por delante que lo que aquí se pretende es identificar grosso modo algunas de las exigencias previstas en la legislación urbanística que a primera vista no se cumplen de forma generalizada y que ponen en entredicho la actuación de las Administraciones Públicas competentes en materia de control de cumplimiento de dicha legislación urbanística.

\section{Antecedentes recientes}

La presencia de edificaciones de distinta condición en el ámbito rural del término de Castalla no es un fenómeno nuevo. Todavía hoy se conservan varios restos arqueológicos de fincas distribuidas por todo el término, frecuentemente propiedad de las familias más adineradas del municipio. Un buen testimonio de ello podemos encontrarlo en las novelas costumbristas del escritor castallense Enric Valor, que relata en algunas de sus obras modos de vida decimonónicos todavía persistentes en los primeros años del siglo XX, y que permiten comprobar cómo en el pueblo de montaña eminentemente rural que entonces era Castalla proliferaban este tipo de explotaciones a las que acompañaban masías de dimensiones nada modestas, muchas de las cuales incluso incluían capillas propias y cuyos restos han llegado a la actualidad.

Más allá del testimonio histórico que puedan representar estas edificaciones, avanzando en el tiempo hasta décadas más cercanas destaca la proliferación de pequeñas casas de aperos muy rudimentarias (véase fotografía 3), en las que bastaba un techo en el que cobijarse el agricultor en caso de lluvia o nevada, un pequeño hogar en el mejor de los casos, y una puerta con la que cerrar la edificación para guardar en ella los aperos propios de la función de labranza. A modo puramente anecdótico, por pintoresco y por excepcional, se podría traer a colación la existencia de este tipo de espacios ya no construidos en ladrillo, sino excavados en las riberas de los bancales directamente sobre la roca, allí donde ésta aflora y lo permite. 
Ya en el último tercio del siglo XX la industria de Castalla y alrededores empezaba a consolidarse como motor económico de la zona, con abundante carga de trabajo y un dinamismo que permitió el auge de las clases medias en la población. En cierto modo podríamos vincularlo al propio devenir de la economía española a partir del desarrollismo impulsado por el régimen franquista. Las mejoras laborales conseguidas en esas últimas décadas del siglo XX colaboraron del mismo modo a la instauración de una clase media generalizada; quizás entre las más ilustrativas fueran las vacaciones pagadas y el impulso al turismo de masas, tan significativo a todos los efectos en la Historia reciente de España.

\section{Fotografía 3. Una de las casas de aperos que quedan a las puertas de una parcela de olivos.}

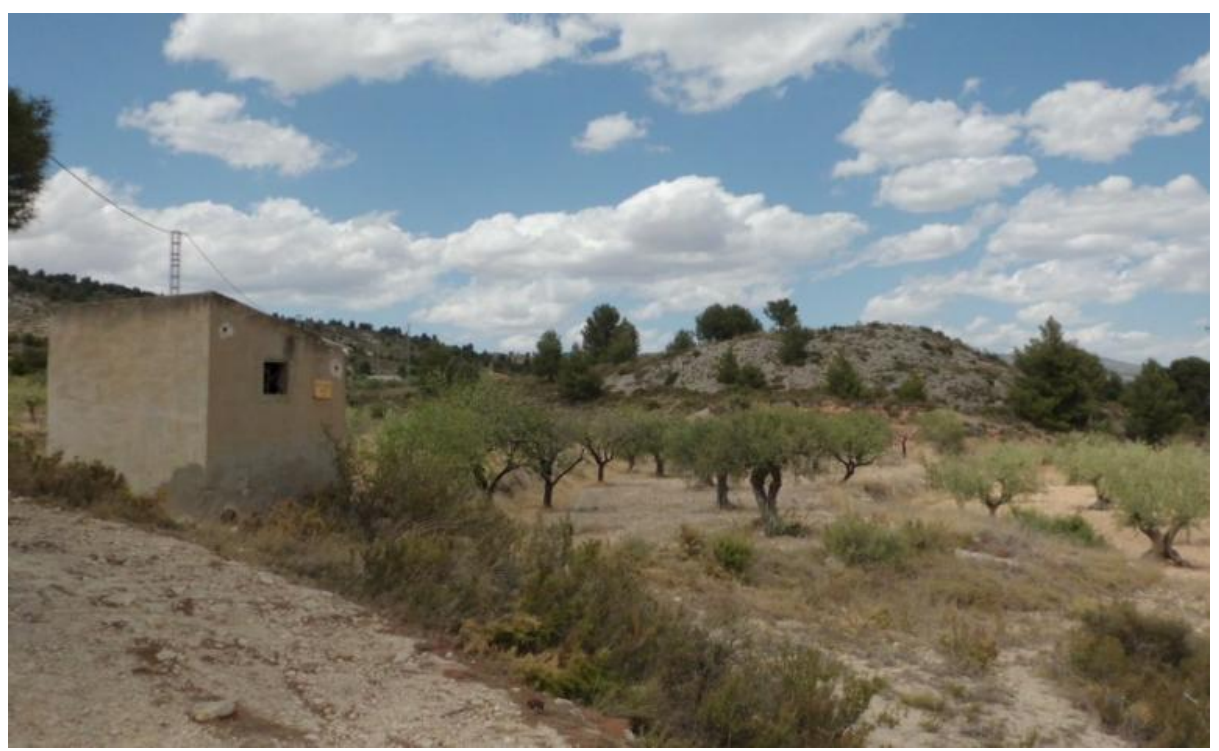

Autor: Sergi Esteve Rico (mayo de 2014)

Así, es muy frecuente conocer por los testimonios de los vecinos hoy de mayor edad (que en las décadas de los años 1970 y 1980 formaban las cohortes más abultadas de la población adulta) cómo esas casas de aperos fueron ampliándose de una forma absolutamente espontánea, buscando las familias un lugar al que acudir en los periodos de vacaciones o días festivos, normalmente a modo de excursión y sin llegar a pernoctar. Esto se facilitaba mucho con la democratización del vehículo particular, que permitía el cómodo acceso por los antiguos caminos agrícolas. Otro factor importante para la generalización de estos nuevos usos de los campos está en el propio minifundismo generalizado que hacía que muchos propietarios contasen con parcelas demasiado pequeñas como para ofrecer un rendimiento que al menos justificara el trabajo que en ellas había que invertir de seguir destinándolas a uso agrícola, a lo que cabe añadir lo habitual que resultaba y sigue resultando que un mismo propietario cuente con varias parcelas pequeñas alejadas entre sí y que acaban por hacer extremadamente complejo cualquier mecanización o aplicación de otras modernizaciones, lo que acaba por llevar a que los propietarios conciban las tierras más como un activo seguro en el que mantener sus rentas que como un verdadero factor de producción. 
Muchas de las viviendas más antiguas que existen hoy dispersas por el término municipal de Castalla surgen de la sucesiva ampliación de las antiguas casas de aperos. Comúnmente se trata de ampliaciones continuadas, realizadas a lo largo de los años por los propios propietarios que invertían su tiempo libre y los ahorros que permitía esa mejora en la situación socioeconómica general en construir una pequeña casa en el campo de la que poder disfrutar en un futuro y que pudiera pasar a engordar el patrimonio familiar susceptible de ser heredado por los hijos. Así, la finalidad agraria no sólo de las antiguas casas de aperos, sino también de los propios campos, pasaba a un plano totalmente secundario. El último estadio que alcanzaban muchas de estas construcciones no deja de ser francamente llamativo, como es la existencia de bastantes pequeñas edificaciones que difícilmente pueden considerarse vivienda por no contar siquiera con habitaciones (son muchas las que solamente cuentan con una cocina y una habitación relativamente grande que hace las veces de comedor y sala de estar) pero que sin embargo sí cuentan con una pequeña balsa a modo de piscina en el exterior, lo que demuestra esa reconversión a un uso eminentemente de ocio de los terrenos antes agrarios. Huelga decir que en todo caso, y pese a la existencia de legislación sobre suelo al menos desde mediados del siglo XX (Ley del Suelo de 1956), los procesos aquí explicados se producían de forma absolutamente espontánea y al margen de cualquier disposición legal; los resultados parecen indicar que la acción de seguimiento de las actividades susceptibles de ser reguladas por dichas leyes brillaba por su ausencia.

Ya mucho más recientemente surge un nuevo proceso que debe distinguirse del anterior. Sobre todo a partir de las décadas de 1990 y 2000 (en algunos casos ya a partir de 1980) el proceso urbanizador del espacio rural toma otro cariz, protagonizado esta vez en la mayoría de ocasiones por una nueva generación, hijos de quienes protagonizaron la anterior. En esta ocasión las nuevas edificaciones no surgen por ampliación de construcciones preexistentes, sino que mayoritariamente se trata de viviendas ex novo, para las cuales se libera terreno cultivado y se cimienta de cero una estructura completamente nueva, en muchas ocasiones acompañada ya desde el primer momento o muy pocos años después por la correspondiente piscina. Por tanto hay dos diferencias sustanciales respecto de las primeras, dado que la vivienda se construye desde cero con una clara voluntad por proveerse de una segunda residencia en el campo, alejada del ritmo urbano del núcleo de Castalla (ya se apuntaba con anterioridad que no se puede considerar estadísticamente como ciudad, pero sí es cierto que el rápido crecimiento urbano del núcleo en pocas décadas da la sensación a quienes vivieron dicha evolución de estar ante una nueva realidad que nada tiene que ver con la Castalla de mediados del siglo XX, ahora ya marcada por una fuerte personalidad industrial); por otro lado, una segunda diferencia la encontraríamos en la propia finalidad de la vivienda, puesto que esta vez sí la mayoría de construcciones incorporan habitaciones y se pretende con ellas ofrecer una residencia estacional de modo que los propietarios frecuentemente pasan los veranos en el campo y los inviernos en el núcleo urbano, una óptica muy alejada de las excursiones en domingos y festivos propias de las casas de aperos ampliadas que no estaban en condiciones de hacer las veces de vivienda, careciendo en muchas ocasiones incluso de electricidad.

El estudio diferenciado de ambas realidades se presenta, no obstante, complejo. Partimos de que en la inmensa mayoría de los casos se trata de construcciones, unas y otras, al margen de la legalidad urbanística primero estatal durante la dictadura y la transición y luego autonómica una vez los distintos Estatutos de Autonomía asumen las competencias en ordenación del territorio y urbanismo. Una primera visita al catastro ya 
permite comprobar cómo muchas de las construcciones existentes no se reflejan en la información cartográfica con que cuenta el Ministerio de Hacienda.

\section{Ejemplos que constatan una realidad ensordecedoramente silenciosa}

La mejor (y probablemente única) forma de demostrar lo aquí expuesto es a través de documentos cartográficos y fotogramétricos. Partiendo de que se tienen fundadas sospechas que buena parte de las viviendas familiares en suelo no urbanizable del término de Castalla se levantaron al margen de la legalidad, resulta del todo inútil pretender encontrar cifras (desde luego oficiales) verosímiles sobre el número de construcciones de estas características que han aparecido en los últimos años en el término. La prueba de que efectivamente así ha sido se encuentra comparando las fotografías obtenidas con los distintos vuelos realizados sobre el territorio en diferentes fechas, además de las imágenes de satélite disponibles. Para ello se han seleccionado tres sectores distintos dentro del término municipal de Castalla, el primero de ellos al suroeste del núcleo urbano, el segundo al sureste y un último al noreste. Así, comparando las fotografías aéreas disponibles del llamado "vuelo americano" (19571958) con las del vuelo nacional de 1980-1986, con las imágenes disponibles del Plan Nacional de Ortofotogrametría Aérea (PNOA) más actuales, relativas al año 2012, se puede observar cómo efectivamente se produce una eclosión de viviendas sobre todo desde los años 1980 (véanse las figuras 7,8 y 9) ${ }^{17}$.

Partiendo de esa realidad y recordando que no es intención del presente trabajo realizar estudio jurídico alguno sobre el estatus de las distintas construcciones, no cabe más que centrar la atención en las viviendas más recientes y observar grosso modo las características que las definen en general y las exigencias legales que a priori no se cumplirían en la mayoría de los casos, sin entrar a estudiar caso por caso ni buscar el marco legal concreto aplicable (por vigencia de las distintas leyes) a cada una de ellas en función del momento en que se construyeran.

\footnotetext{
${ }^{17}$ Fuente: Vuelos fotogramétricos Americano (1956-1957), Nacional (1980-1986) y PNOA máxima actualidad (2012). Disponible en la fototeca del CNIG: 〈http://fototeca.cnig.es/>
} 

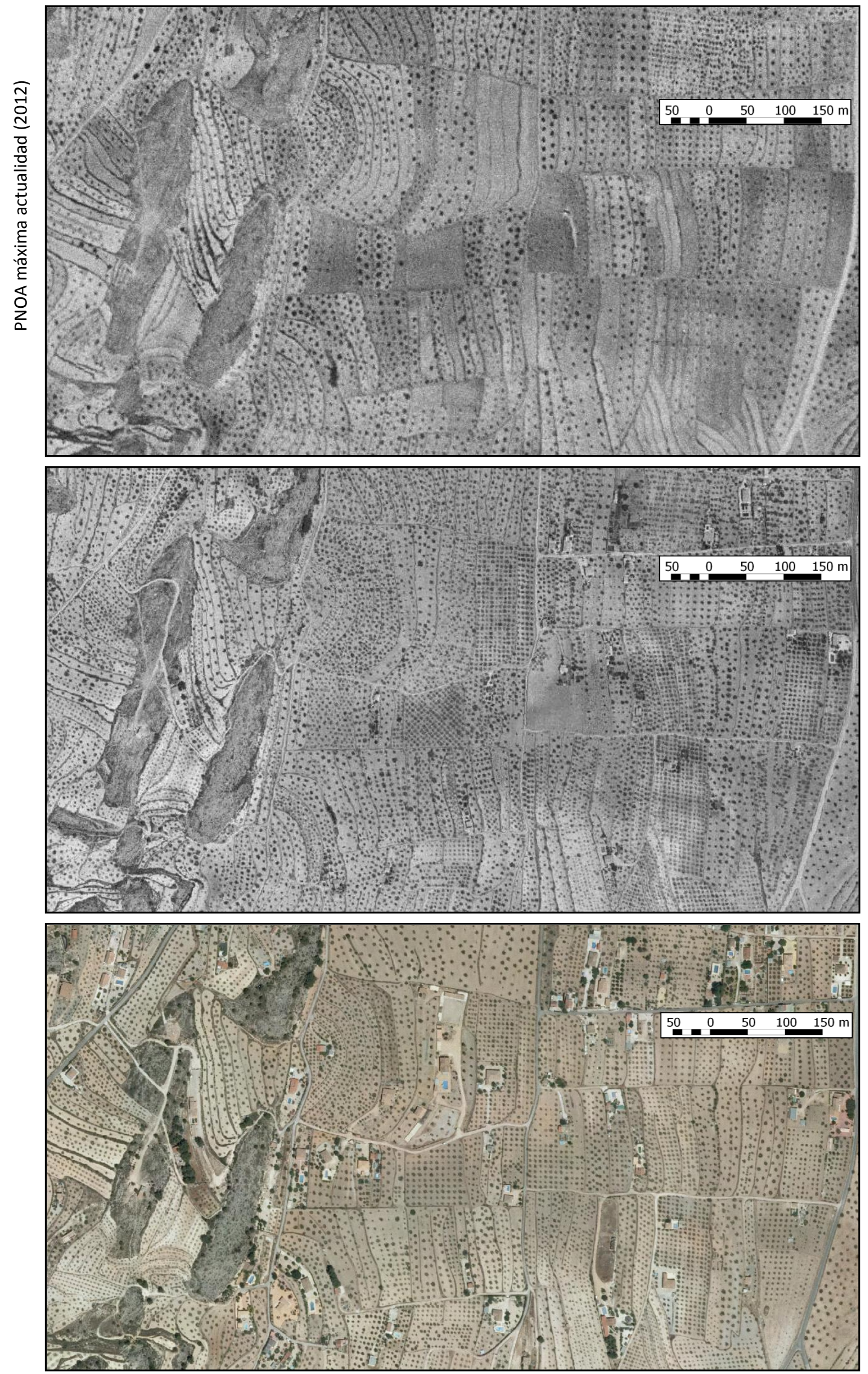

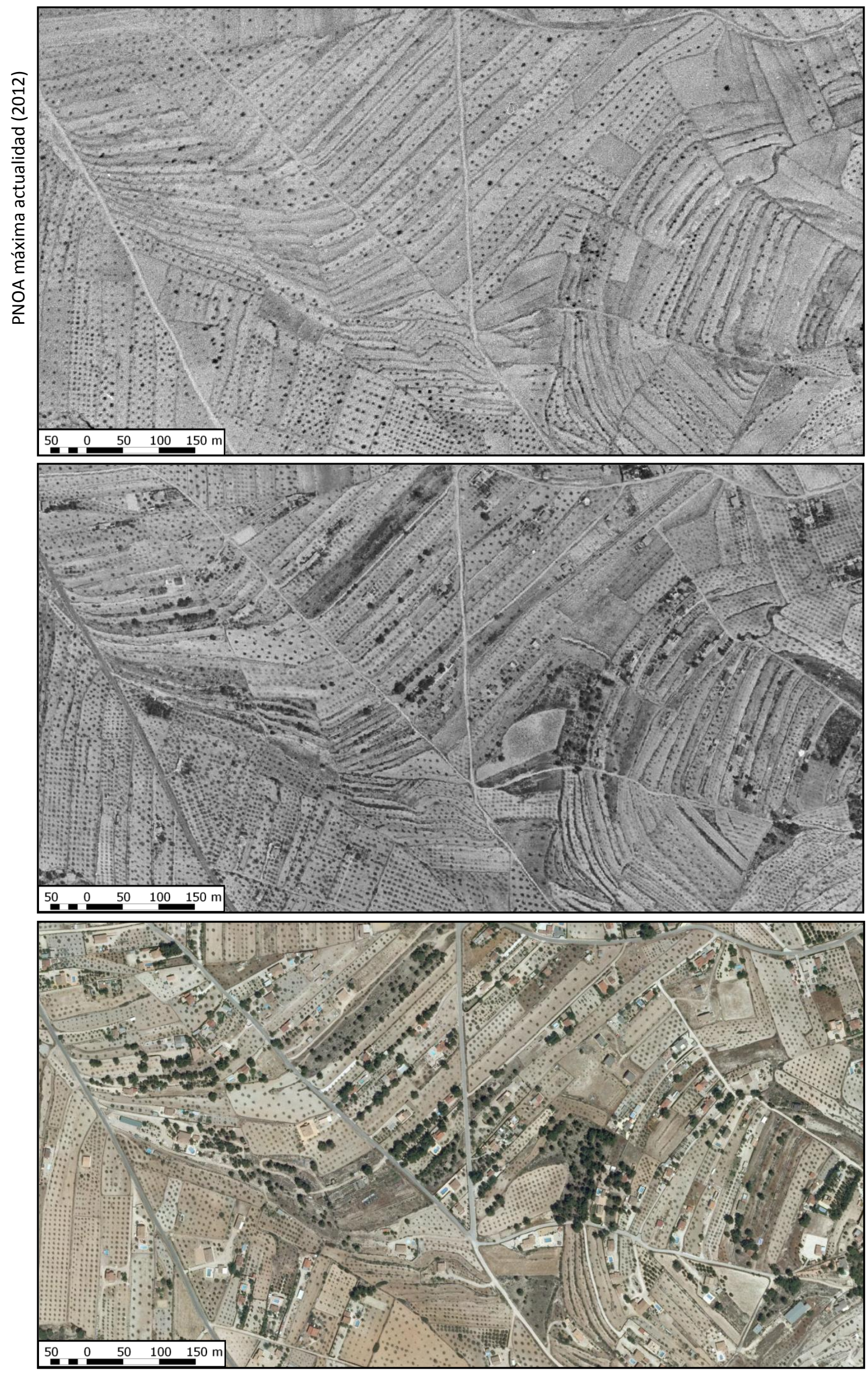

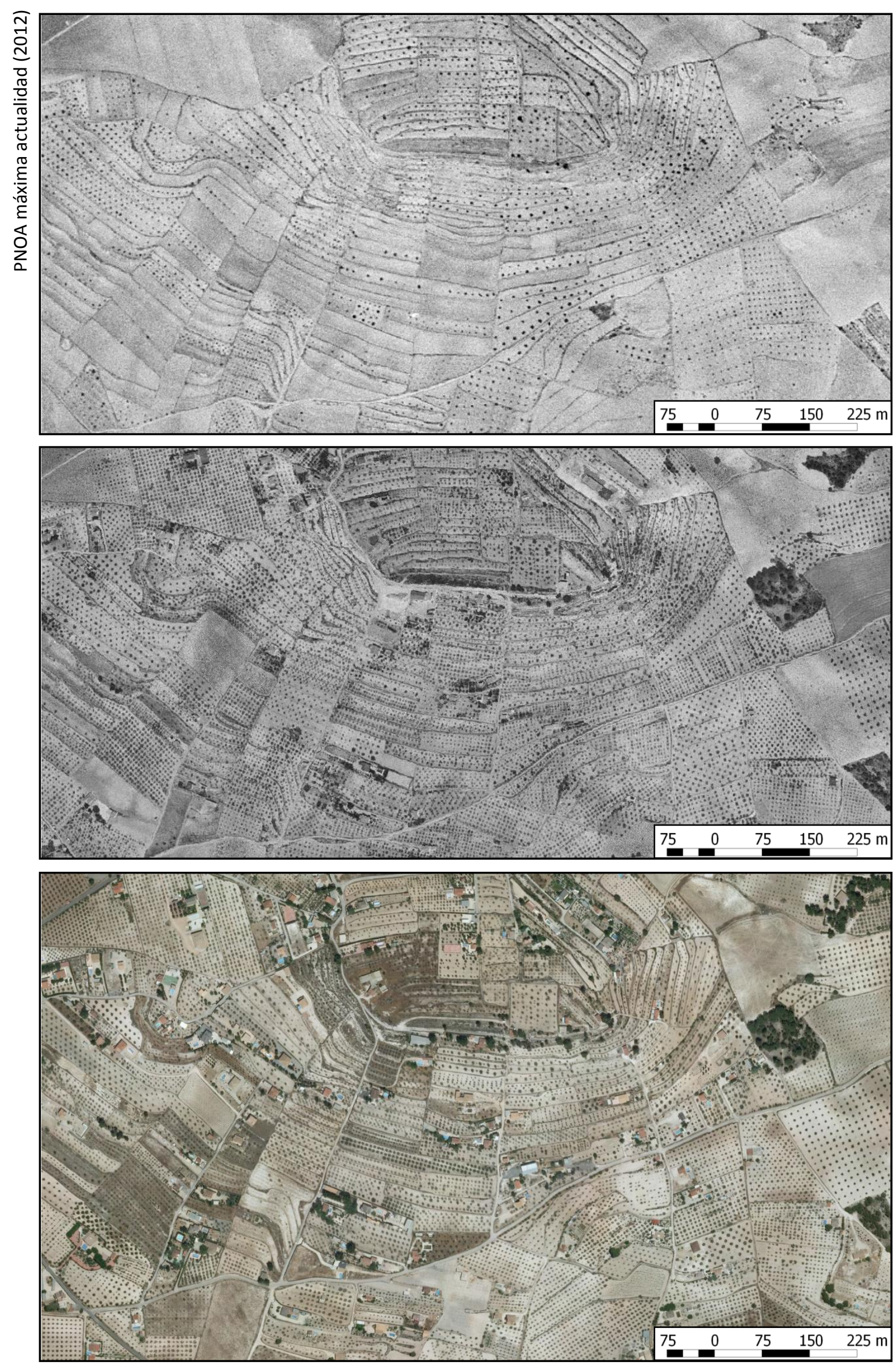


\section{Un vistazo somero a la legislación: requisitos generalmente incumplidos}

La existencia de actividades y actitudes de cuestionable encaje en la legislación en materia de urbanismo en el término de Castalla es un fenómeno ampliamente conocido, no sólo por los habitantes del lugar sino también por juristas especializados en el ámbito urbanístico que en privado llegan a expresar su estupefacción e incomprensión ante la inacción de la administración autonómica. Es una actitud la de la Generalitat Valenciana que contrasta con su intervención en otros municipios de la provincia en los que la infracción urbanística y la permisividad municipal se habían vuelto tónica general. No faltan voces entre la prensa ${ }^{18}$ y los analistas políticos que explican ese distinto trato ante casos semejantes apuntando al distinto color político que gobierna en unos y otros ayuntamientos.

La legislación sobre suelo no urbanizable en territorio valenciano se fijaba en la Ley 10/2004 de 9 de diciembre, del Consell, de Suelo No Urbanizable (en adelante, LSNU 2004) ${ }^{19}$ hasta agosto de 2014, cuando entraría en vigor la nueva Ley de Ordenación del Territorio, Urbanismo y Paisaje (LOTUP 2014). La LSNU 2004, a los efectos aquí planteados, establecía unos criterios básicos que deberían regir, grosso modo, el desarrollo de cualquier actividad en dicha categoría de suelo, que se corresponde con lo que podríamos entender como espacio rural (el "campo"). Son unas pautas las de la LSNU 2004 que en general, para el caso de aquéllas que se mencionan en este artículo, no distan en demasía de lo que recogería su sucesora, la LOTUP 2014.

La LSNU 2004 fijaba una serie de pautas que debían ser respetadas por los Planes Generales de Ordenación Urbana de cada municipio, aunque en muchos casos dejaba margen para que los ayuntamientos que lo deseasen ampliasen algunas restricciones; los municipios podían por tanto endurecer según qué requisitos respecto a lo fijado por la autonomía, pero no suavizarlos. Para garantizar la armonía de los planeamientos municipales respecto a la norma autonómica los Planes Generales de Ordenación Urbana se aprobaban en última instancia por el Consell. Para el término municipal de Castalla el planeamiento vigente a estos efectos es el citado Plan General aprobado el 25/07/2002, anterior incluso a la Ley de Suelo No Urbanizable. Han sido varias las ocasiones en que, desde programas electorales o ya una vez desde los distintos equipos de gobierno se han planteado modificaciones para, entre otros fines, adecuar el PG 2002 a las nuevas normativas autonómicas y la nueva realidad urbanística, aunque ninguno de ellos ha terminado cuajando.

Tomando como marco general la LSNU 2004 y ciñéndonos a las apreciaciones que establece para la construcción de vivienda aislada y familiar, se pueden identificar varios requisitos que a priori se incumplen. Se trata de un aspecto importante porque si bien en las fotografías anteriormente ofrecidas se aprecia cómo el gran desarrollo de la urbanización se produce entre la década de 1980 y la actualidad, el pico principal podríamos identificarlo en los tiempos de burbuja inmobiliaria de la década de los 2000. Por tanto, buena parte de esas viviendas aisladas y familiares que dan sentido a este

\footnotetext{
${ }^{18}$ VELERT, Sara y MOLTÓ, Ezequiel. Territorio retira el control urbanístico a Catral porque tiene 1.270 casas ilegales. Archivo de El País. 04/10/2006. [Consulta: 31/03/2014]. Disponible en: <http://elpais.com/diario/2006/10/04/cvalenciana/1159989479 850215.html>

${ }^{19}$ Ley 10/2004, de 9 de diciembre, de la Generalitat, del Suelo No Urbanizable. En: Diari Oficial de la Generalitat Valenciana [En línea], nº4.900. [Consulta: 17/03/2014]. Disponible en: 〈http://www.docv.gva.es/datos/2004/12/10/pdf/2004_12638.pdf >
} 
artículo aparecieron una vez ya vigente la LSNU 2004. No obstante, como ya se ha apuntado con anterioridad, si de algo debe servir tomar como referencia una legislación u otra debe ser para aferrarse a unos criterios objetivos a través de los cuales se pretenda la conservación del medio rural, y no tanto para buscar ilegalidades urbanísticas sancionables con mero afán punitivo/recaudatorio. Es muy conveniente subrayar esto último, pues demasiado frecuentemente se olvida que la Ley y las infracciones que de ésta se desprendan no deben ser un fin en sí mismas, sino un medio con el que garantizar otros objetivos sin duda más importantes, en este caso la conservación del medio rural y natural.

Quizás uno de los requisitos que más llame la atención por su incumplimiento generalizado sea el criterio de la extensión mínima que deberá tener la parcela. Según determina el artículo 21.2 de la LSNU 2004 corresponde a los planeamientos establecer esos criterios de parcela mínima, pero sí apunta que en ningún caso podrá ser inferior a la hectárea. Así lo ratifica también la LOTUP $2014^{20}$ en su Artículo 197. Ya antes de conocer si el PG 2002 amplía aun más ese requisito y aceptando el criterio más favorable, el de una hectárea que fijan las Leyes autonómicas, podemos afirmar sin ningún tipo de duda que su incumplimiento es del todo generalizado.

El segundo requisito establece que la edificación no podrá superar el $2 \%$ de la superficie de la parcela, también ampliamente incumplido dado que en muchas ocasiones las parcelas son lo suficientemente pequeñas como para que el dos por ciento de las mismas apenas permita levantar un pequeño cuchitril. Una tercera exigencia, por citar otro ejemplo, se refiere a la necesidad de prever suficiente abastecimiento de agua potable y completa evacuación, recogida y depuración de residuos y aguas residuales. Es este último un asunto de especial trascendencia, dado que en la mayoría de los casos las aguas residuales se evacúan directamente a fosas sépticas construidas por los propios propietarios, frecuentemente sin ningún tipo de control o supervisión por parte de la administración pública.

A los efectos buscados en este artículo, si para algo debe servir el criterio legal de los $10.000 \mathrm{~m}^{2}$ de superficie mínima de parcela para poder edificar debe ser para plantear una pauta coherente que delimite a partir de qué densidades de construcción está dispuesta una sociedad (que así lo expresa mediante la legislación emanada de cámaras representativas democráticamente escogidas por la ciudadanía) a consentir para su medio rural (para "su campo"). Sin más información que ésa se puede afirmar contundentemente que es un criterio absolutamente insuficiente; dicho de otro modo: si tomásemos el territorio que consideramos como "campo" y lo dividiésemos en parcelas de $10.000 \mathrm{~m}^{2}$ (esto es, una hectárea) y edificásemos en cada una de ellas una vivienda unifamiliar, la densidad resultante provocaría bochorno. La pauta de $10 \mathrm{~s} 10.000 \mathrm{~m}^{2}$ sólo cobra algo de sentido cuando se conjuga con una realidad de minifundismo imperante en la que las parcelas que superan este umbral no abundan en absoluto.

Cabe no perder nunca de vista que el propio nombre que se da en la clasificación a estos terrenos es perfectamente expresivo: suelo no urbanizable; es decir, aquél en el que la urbanización, si no ausente, debe ser una absoluta excepción. Qué duda cabe, recuperando las figuras 7,8 y 9 , de que algo no se ha hecho bien de un tiempo a esta

\footnotetext{
${ }^{20}$ Ley 5/2014, de 25 de julio, de la Generalitat, de Ordenación del Territorio, Urbanismo y Paisaje, de la Comunidad Valenciana. Diari Oficial de la Generalitat Valenciana [en línea], nº7.329. [Consulta: 15/08/2014]. Disponible en: <http://www.docv.gva.es/datos/2014/07/31/pdf/2014_7303.pdf>
} 
parte, sea por incumplimiento de la norma o por ineficiencia de ésta, aunque todo apunta a que es la primera de las circunstancias la que se ha dado masivamente. En algunos sectores, como es perfectamente comprobable a través de fotografía aérea, las densidades llegan a asemejarse a las existentes en los modelos teóricos de ciudad-jardín promovidos por el urbanista británico Ebenezer Howard, que desde luego desplazan o incluso sustituyen el tradicional uso agrícola de las parcelas, por pequeñas que resulten.

\section{Figura 10. Detalle de un sector del término municipal de Castalla, al sureste del núcleo urbano. Vista del PNOA (izquierda). Cartografía catastral (derecha)}
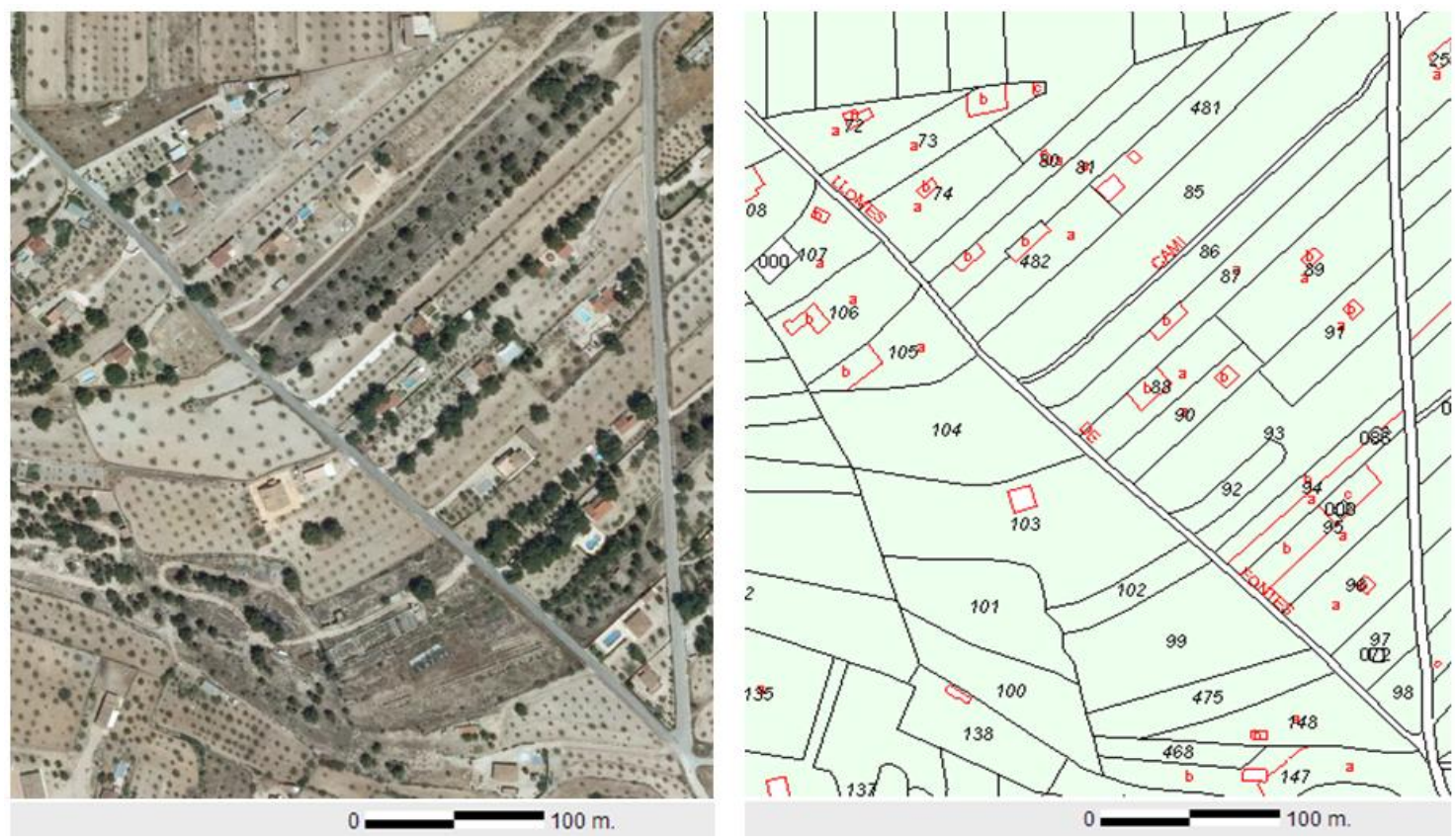

Fuente: PNOA máxima actualidad (2012) y Sede Electrónica del Catastro, Ministerio de Hacienda y Administraciones Públicas.

La figura 10 da buena prueba de ello; se trata de una zona situada al sureste del núcleo urbano de Castalla, con multitud de viviendas surgidas en parcelas que, salvo la identificada con el número 85 (que paradójicamente no cuenta con edificación), no alcanzan ninguna de ellas los diez mil metros cuadrados de superficie, tal y como se especifica en la cartografía y fichas disponibles en el catastro ${ }^{21}$. Ello no excluye, sin embargo, que buena parte de las viviendas sean anteriores tanto a la LSNU 2004 como al PG 2002.

De las condiciones generales que no se respetan para suelo no urbanizable destacan por un lado la de retranqueo mínimo de cinco metros respecto a cualquier lindero, que frecuentemente se vulnera por el simple hecho de que las parcelas son, como ya se ha apuntado, más bien modestas en superficie y se tiende a emplazar la vivienda cerca de los linderos para dejar así grandes espacios libres que permitan emplazar piscinas, jardines u otros espacios abiertos. Por otro lado, resulta llamativo lo subjetivo del criterio de "deberá cuidar al máximo su diseño y elección de materiales, colores y

\footnotetext{
${ }^{21}$ Sede Electrónica del Catastro. Ministerio de Hacienda y Administraciones Públicas [En línea]. [Consulta: 17/04/2014]. Disponible en: 〈https://www1.sedecatastro.gob.es/>
} 
texturas a utilizar, tanto en paramentos verticales como en cubiertas y carpinterías, con el fin de conseguir la máxima adecuación al entorno" ${ }^{22}$; muy discutible su cumplimiento habiéndose constatado la presencia de edificaciones con las fachadas pintadas, por ejemplo, de azul.

\section{Efectos sobre la agricultura}

No se puede, en otro orden de ideas, obviar el comentario sobre las consecuencias que el creciente desarrollo urbanístico ha tenido sobre la actividad por antonomasia del medio rural y que desde siempre lo ha definido como tal: la agricultura. A efectos agrícolas se podría pensar a primera vista que tanto el abandono progresivo de la actividad como sector económico de peso, como la transformación de parcelas antes de uso agrícola a uso residencial, se traduciría en una merma de la producción de unos años a esta parte.

La agricultura de Castalla se resume básicamente en tres grandes cultivos que copaban el $93,77 \%$ de la superficie cultivada del municipio en el año 2012, según las estimaciones de la Conselleria de Presidencia y Agricultura, Pesca, Alimentación y Agua disponibles en el IVE $^{23}$. Son, en este orden, el olivar (1.188 Ha cultivadas, un $46,2 \%$ del total de tierras cultivadas), el almendro (964 Ha, un 37,5\% del total) y la viña (257 Ha, un 10,0\% del total). Son cultivos en su mayoría de secano $(87,6 \%$ ), con porcentajes que rondan el noventa por ciento en el caso del olivar y el almendro y que descienden a poco menos del setenta por ciento para el caso de la viña, en la que la superficie de regadío es más significativa. Tomando como referencia las mismas estimaciones ofrecidas por el IVE para el año 2002 (el más antiguo de la serie), se puede observar cómo los tres cultivos han perdido superficie de cultivo en dicho intervalo, unas mermas del $20,2 \%$ en el caso del olivar, del $16 \%$ en el caso de los frutales no cítricos (de los cuales el almendro supone porcentajes que rondan el noventa por ciento en el caso de Castalla, luego resulta un dato significativo), y hasta el 48,6\% en el caso de la viña, desplome este último justificado por la incidencia de las políticas desincentivadoras de la PAC.

Llama y mucho la atención que pese a la continuada reducción de tierras destinadas a estos cultivos, las producciones no necesariamente se ven disminuidas en consonancia. En el caso del olivar, por ejemplo, la producción de aceituna se ha ido incrementando paulatinamente desde la temporada 1990/1991 hasta la actualidad, y por consiguiente del mismo modo lo ha hecho la producción de aceite que se extrae de esas aceitunas, como muestra la figura 11.

\footnotetext{
${ }^{22}$ Normas urbanísticas, Art. 6.14. Plan General del Término Municipal de Castalla [En línea]. 25/07/2002 [Consulta: 18/04/2014]. pp. 71-74. Disponible en: <http://www.cma.gva.es/contenidoHtmlArea/contenido/30231/cas/NNUU.pdf>

${ }^{23}$ Estimaciones de superficies de cultivo por municipios: superficies según grupo de cultivo y tipo de riego y superficies de los principales cultivos de frutales no cítricos según tipo de riego. Banco de datos territorial del Instituto Valenciano de Estadística (IVE) [en línea]. [Consulta: 18/04/2014]. Disponible en: <http://www.ive.es/>
} 
Figura 11. Producción de aceituna y aceite en la Bodega Cooperativa de Castalla (temporadas 1990-1991 a 2013-2014)

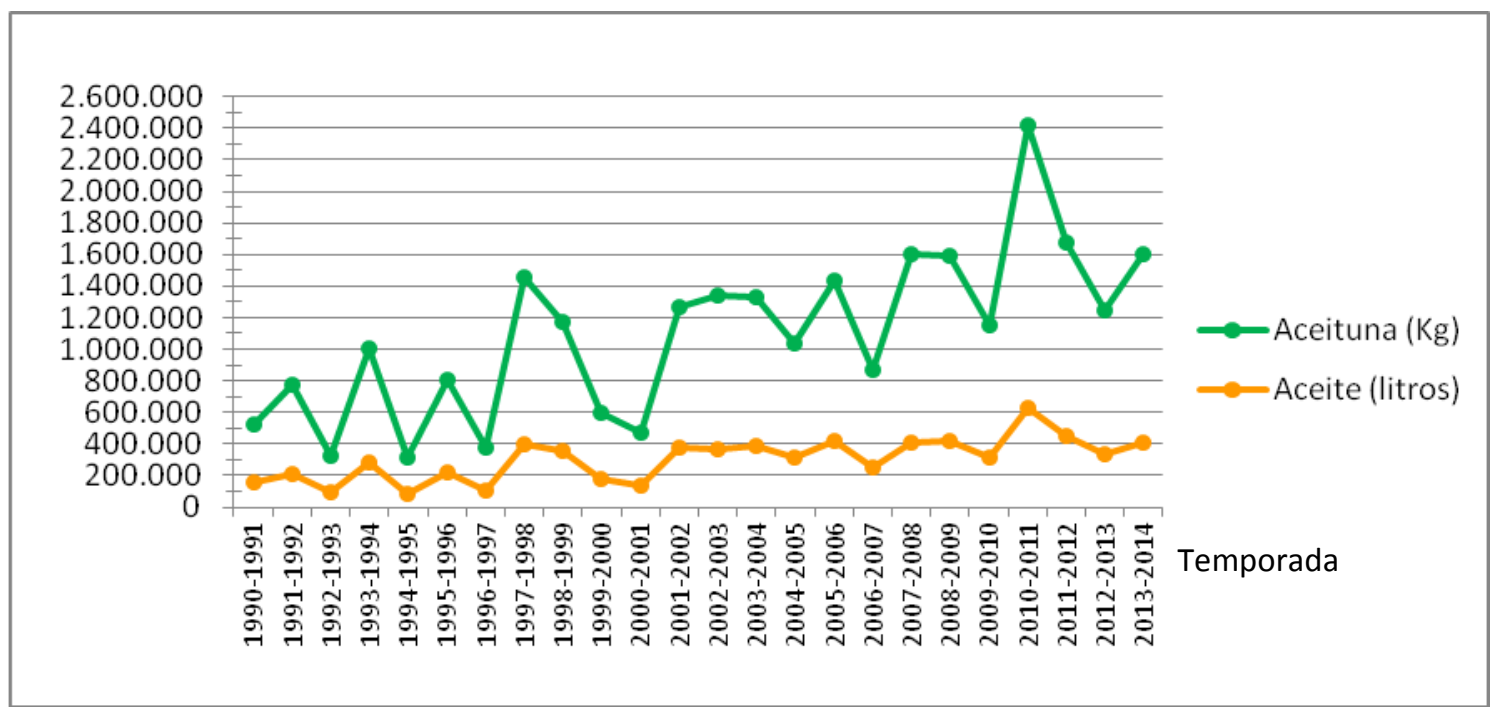

Fuente: Datos ofrecidos por la Bodega Cooperativa de Castalla. Elaboración propia.

Obviamente los altibajos que muestra el gráfico se deben a las variaciones de un año a otro que se achacan principalmente a factores meteorológicos, con especial incidencia sobre los cultivos de secano. Hay que tener en cuenta, sin embargo, que aunque la Bodega Cooperativa de Castalla está compuesta por una mayoría de socios del municipio, también recoge producción de otros términos municipales que podrían alterar levemente los datos aquí registrados, aunque grosso modo pueda considerarse como un termómetro fiable de la situación del cultivo de olivar en Castalla. Si bien eso es cierto, hay que apuntar que el gran pico registrado en la temporada 2010-2011 se debe tanto a la buena cosecha de ese año como al cierre de la cooperativa agrícola de Ibi cerca de la campaña de recogida de la aceituna, lo que contrajo una avalancha de nuevos socios tanto en la cooperativa de Castalla como en la de la vecina Onil ${ }^{24}$. De hecho, el número de socios de la Bodega Cooperativa de Castalla crece de una forma casi constante a lo largo del periodo reflejado en la figura 11 hasta el año 2011 en el que registra un salto de más de 400 socios por este motivo, y que hay que tener en cuenta también a la hora de interpretar los datos de producción ofrecidos.

Para la producción de almendra, la fuente más cercana a la realidad municipal castallense es la que ofrece la Sociedad Cooperativa Agrícola "Montaña-Vinalopó", comúnmente conocida como "la Trencadora". Sus registros tanto de socios como de producción de almendra desde 1980 hasta 2010 (por décadas) reflejan también un crecimiento continuado en ambas variables; en el caso de la producción se pasa de $850.000 \mathrm{Kg}$ de almendra en 1980 a $1.150 .000 \mathrm{Kg}$ en 2010. De nuevo cabe apuntar que estos datos, pese a pertenecer a una cooperativa afincada en Castalla, no se corresponden a producción exclusiva del término.

\footnotetext{
${ }^{24}$ SERRANO, C. La cooperativa de Castalla registra una avalancha de socios tras cerrarse la de IBI. Diario Información [En línea]. 18/01/2011 [Consulta: 19/05/2014]. Disponible en: <http://www.diarioinformacion.com/alcoy/2011/01/18/cooperativa-castalla-registra-avalancha-socioscerrarse-ibi/1085446.html>
} 
Esta última circunstancia, común en los datos amablemente ofrecidos por las dos cooperativas agrícolas impide afirmar fehacientemente que pese a la reducción de tierras dedicadas a estos cultivos la producción se haya mantenido al alza. Sin embargo, dejando de lado este criterio tan estrictamente cuantitativo y prestando atención a las impresiones de quienes durante años han mantenido una relación muy estrecha con la actividad agrícola en Castalla, que no son otros que los agricultores de mayor edad hoy jubilados que siguen sin embargo dedicando su tiempo a sus parcelas, la conclusión que se extrae es que efectivamente sí se produce más hoy en día que años atrás. Tómese esta conclusión como lo que es, fruto de impresiones totalmente subjetivas sacadas de las más informales conversaciones, pero que no dejan de tener su relevancia teniendo en cuenta el estrecho contacto de estas personas con el campo de Castalla. Nos encontramos por tanto ante una circunstancia un tanto paradójica.

Desde luego cualquier intento por vincular el auge del residencialismo diseminado con las a priori mejores cifras de producción agrícola (pensamos en las impresiones aquí referidas, no en los datos) resultaría extremadamente complejo de argumentar desde un punto de vista racional; no se puede pensar que es gracias a que actualmente el campo de Castalla aparece plagado de chalets que la agricultura presenta mejor cara. En todo caso la mejora de la producción debe relacionarse con mejoras en las técnicas, que pasan desde luego por la utilización generalizada de químicos, el arado mecanizado de los campos, o incluso los avances en la maquinaria de que disponen las cooperativas para la producción del aceite y el vino y la extracción de la almendra de su cáscara.

De este modo, por ofrecer otra perspectiva más amplia que corrobora este razonamiento, si remontásemos la vista a la situación del campo en la Castalla de principios de siglo, tan magníficamente retratada por el novelista costumbrista castallense Enric Valor en su obra Sense la terra promesa ${ }^{25}$, nos encontraríamos ante un panorama en el que la agricultura estaba muchísimo más generalizada como actividad económica que hoy en día (la industria sólo tomará un cuerpo apreciable a partir de mitades del siglo XX, y los servicios serán todavía posteriores) y las tierras en cultivo se extendían hasta el punto de configurar abancalamientos en zonas abruptas para ganar terrenos a la montaña ante el colapso de las tierras llanas del fondo del valle (no es el único factor, también se buscaba evitar la pérdida de escorrentía en las laderas), bancales generalmente abandonadas hoy en día, sobre todo los más alejados del núcleo. Sin embargo, los rendimientos de la agricultura en términos relativos, careciendo como se carecía de los avances técnicos actuales, no se pueden comparar con los que ofrece una agricultura mecanizada y abastecida de químicos.

\section{El impacto medioambiental y paisajístico de la urbanización diseminada}

Pero sin duda el principal problema que plantea la eclosión de este tipo de poblamiento diseminado juega en otro plano. Desde luego el daño paisajístico es más que constatable, aunque quizás la configuración del relieve lleva a que esa ocupación quede un tanto disimulada. No se puede afirmar que el paisaje de la Hoya de Castalla haya sufrido un cambio radical con el surgimiento de estos asentamientos, dado que su propia naturaleza de valle hace que su visibilidad sea mucho menor que la que se aprecia en otros enclaves de la provincia muy castigados también por el auge urbanístico, sobre

${ }^{25}$ VALOR i VIVES, Enric. Sense la Terra Promesa (Cicle de Cassana, I) [En catalán]. Tàndem, 1999. 
todo en el litoral; un magnífico a la par que triste ejemplo lo encontraríamos en Calpe. Todo ello no quita, obviamente, que también en Castalla se dé ese impacto paisajístico. De entre los perjuicios más puramente naturales el caso de las posibles filtraciones de las aguas residuales se ha mentado ya, aunque conviene profundizar algo más en esta realidad.

Se trata de uno de los impactos que más preocupación debería suscitar (y que, inexplicablemente, parece no despertar ningún interés a las administraciones públicas). El surgimiento improvisado de los asentamientos lleva a que la planificación de servicios esenciales como la electricidad, el agua o el saneamiento tomen tintes especialmente complejos. Los dos primeros, por imprescindibles, terminan por implementarse de una forma $\mathrm{u}$ otra, pero el saneamiento ofrece posibilidades más asequibles en forma de construcción de fosas sépticas, frecuentemente instaladas por los propios propietarios y sin el debido control por parte de las administraciones públicas, que de una forma absolutamente temeraria "confían" en el buen hacer de los propietarios a la hora de asegurar todas las garantías necesarias para evitar filtraciones de aguas sin depurar, por ejemplo. Si se recupera la ya citada presencia de pozos para suministro de agua, el problema se manifiesta por sí solo.

Existen también otros riesgos que suelen obviarse como la introducción desmesurada de especies alóctonas, que como tales no entienden de límites parcelarios y que en algunos casos pueden suponer una amenaza para las autóctonas. Recuperando la problemática que supone el desvío de las aguas residuales a fosas sépticas carentes de control por parte de la administración, se aventuraría ya otra de las facetas que debe tomarse en consideración a la hora de abordar este tema. Se trata de la oferta de servicios básicos municipales que en los núcleos urbanos todo el mundo recibe. La ausencia de saneamiento mediante alcantarillado público está absolutamente generalizada salvo en algunos casos muy concretos de viviendas muy cercanas al núcleo urbano de Castalla en las que, encontrándose presumiblemente en situación legal, se abría la posibilidad de extenderles la red de alcantarillado. Son en todo caso excepciones muy contadas, ya que por lo general lo que prima es la apertura de una fosa séptica por parte del propietarioconstructor (ambas personalidades suelen coincidir). El caso del abastecimiento de agua potable y de la electricidad es bien distinto, estando ambos suministros muy ampliamente extendidos; esto se plasma en una auténtica invasión de cableado eléctrico que, pasando muchas veces desapercibido por lo acostumbrada que está la población a su presencia también en las ciudades, se extiende por zonas agrícolas teniendo forzosamente que apoyarse en torretas que salpican aquí y allá los márgenes de las parcelas, e incluso imponiéndose en las manchas de bosque bajo y bosque alto que en algunos lugares se intercalan entre los campos. Del mismo modo ocurre con las tuberías que llevan el agua, aunque en este caso al ir enterradas pasan totalmente desapercibidas y tan sólo ofrecen testimonio de su presencia los contadores que se suelen ver a las puertas de las parcelas. Tantas son las comodidades que hoy en día se extienden al poblamiento diseminado que en los últimos años han aparecido incluso empresas locales que ofrecen servicio de "internet rural" respondiendo a la creciente demanda.

Más allá de estos equipos e infraestructuras el verdadero problema aparece a la hora de prestar servicios como la recogida de basuras o el reparto de correos. Éste último se acaba solventando mediante el alquiler de apartados postales en las oficinas de Correos, pero la recogida de basuras se presenta mucho más problemática. A efectos logísticos resulta absolutamente inviable que los servicios de recogida recorran todos los caminos 
rurales que se extienden en los alrededores de Castalla. Lo que se ha acabado haciendo es tomar un remedio que en cierto modo soluciona el problema más inmediato pero que a todas luces resulta insuficiente.

A lo largo de estos caminos rurales se han instalado contenedores en puntos más o menos estratégicos que atienden áreas relativamente extensas para que los vecinos depositen (o así deben hacerlo) sus residuos de forma centralizada. Estos contenedores aparecen identificados como destinados a albergar residuos exclusivamente orgánicos, por lo que en cualquier caso el Ayuntamiento puede justificar su presencia allí por la sola presencia de una actividad agrícola que obviamente genera desechos de este tipo. Sin embargo, la realidad demuestra que en ellos se depositan residuos absolutamente variopintos, incluyendo mobiliario y objetos de lo más insospechado, que los servicios de recogida no tienen el menor reparo en, valga la redundancia, recoger junto a la materia orgánica. Se presenta por tanto un foco clarísimo de atentado contra el reciclaje, práctica sostenible que se ha ido generalizando de un tiempo a esta parte no sin dificultad y que choca sin embargo con realidades como la aquí expuesta. Al mismo tiempo, no parece que la mejor forma de fomentar la limpieza en el medio rural sea ésta, puesto que se abre la puerta a que aparezcan vertederos ilegales en cunetas o cualquier otro recoveco. Por encontrar una última pega que destacar en lo referente a la instalación de estos contenedores, cabría citar el pésimo estado de conservación de algunos de ellos, ya no sólo por los desperfectos que puedan presentar (que también), sino sobre todo porque en algunos casos acaban creando auténticos puntos de suciedad e insalubridad por los fluidos que de ellos se desprenden y los residuos que se acumulan, desembolsados, en sus alrededores.

Fotografía 4. Uno de los muchos puntos de recogida de basura orgánica en un camino rural, a 1'3Km del núcleo urbano. Destacan el cartel que reza "sólo basura orgánica" y la abundante suciedad que se acumula en los alrededores.

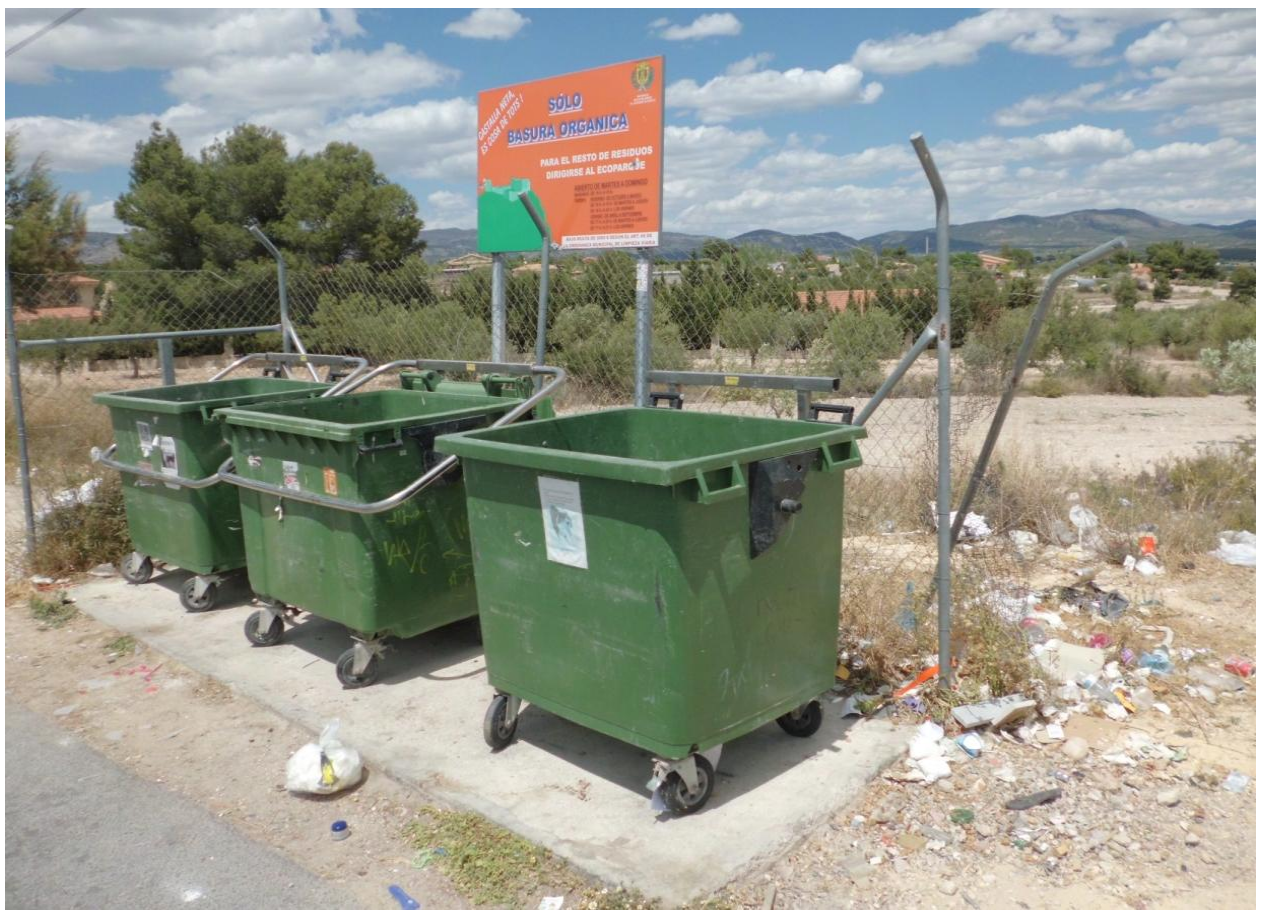

Autor: Sergi Esteve Rico (mayo de 2014) 


\section{¿Responsables? Recuérdese el verdadero cariz del problema}

Llegados a este punto, resulta a todas luces interesante recuperar la reflexión del abogado Antonio Cano Murcia en su libro El Régimen Jurídico del Suelo No Urbanizable o Rústico:
«[...] Todo ello nos conduce a la conclusión de que es la Administración municipal la que tiene en sus manos el control de la actividad urbanística, y que empleando todos los medios que la normativa urbanistica pone en sus manos, ha de evitar la conclusión de obras ilegales en suelo no urbanizable. El principio de intervención mínima que inspira el ordenamiento punitivo no es sino una llamada de atención a los órganos urbanísticos competentes para que actúen. De lo contrario nos encontraríamos ante una dejación de funciones, ante un dejar hacer del infractor porque ya vendrán los Tribunales de Justicia a poner remedio. ¿No estaremos ante una prevaricación por omisión? Ocioso resulta recordar las obligaciones de los órganos municipales competentes, una vez detectada la existencia de una infracción urbanística, que se lleve hasta sus últimas consecuencias el resultado del ilícito urbanístico (legalización, si procede; demolición; sanción; multas coercitivas).» (Cano, 2006, p.355-356).

Desde luego el papel de los equipos de gobierno que se han sucedido en la alcaldía de Castalla durante los años del boom urbanístico resulta más que cuestionable. Es la administración local la que ejerce las competencias de control de la legalidad urbanística y la imposición de sanciones, salvo negligencias manifiestas por parte de dicha administración local, en cuyo caso la Conselleria competente podría (debería) intervenir (Cantó, 2007, p. 175-176), tal y como llegó a ocurrir en municipios como Catral. Podríamos perfectamente en este punto recordar las reflexiones que se exponían en el estudio sobre la corrupción urbanística de los investigadores de la Universidad de La Laguna y que dejaban entrever que en lo que a corrupción se refiere no se actúa de la misma forma cuando el gobierno municipal y el regional coinciden en signo político (caso de Castalla) y cuando no.

No obstante, las reflexiones que todo lo aquí expuesto debe suscitar han de trascender lo meramente punitivo. Interesaría que los esfuerzos se centrasen en buscar soluciones, mecanismos y vías que permitan encauzar una situación desmadrada y logren atajar una serie de problemáticas cuyo mayor perjudicado en el fondo no es tanto una legalidad violada (en el caso de que así sea) sino un medio duramente acosado. La reacción no puede quedar en un mero arrebato sancionador (y mucho menos demoledor); denotaría una falta absoluta de comprensión del cariz del problema.

\section{CONCLUSIONES}

En los últimos años la actividad urbanística ha gozado de una permisividad pasmosa por parte de las administraciones públicas. En demasiadas ocasiones la concepción del suelo como un bien de consumo susceptible de ofrecer beneficio económico ha logrado eclipsar la voces críticas que recordaban que el suelo es también uno de los factores más difíciles de recuperar una vez abordado por el frenesí de la construcción. El caso de 
Castalla, especialmente en la ampliación del núcleo urbano de los últimos años, resulta paradigmático en este sentido.

Es sin duda ése uno de los aprendizajes más importantes que se deben interiorizar vistos a posteriori los desastrosos efectos del desenfreno urbanístico que hace escasos años protagonizaba el desarrollo económico español en general y de su litoral y prelitoral mediterráneo en particular. No es el único, sin duda, pues como se exponía en el tramo final de este artículo otra de los aprendizajes básicos que deben asimilarse radica en la evidencia de que el beneficio económico a corto plazo ofrece generalmente resultados nocivos a largo plazo, también en lo económico, y sobre todo cuando con la actividad urbanística tiene el asunto que ver. La pretensión de algunas corporaciones municipales de engordar las recaudaciones a partir de los impuestos más directamente vinculados a la compra de vivienda se han demostrado absolutamente irresponsables dado que se ha querido obviar que esas ampliaciones del hecho urbano acaban requiriendo de unos servicios y unas dotaciones que se tienen que sufragar también por parte de la administración pública; del mismo modo, el argumento de la creación de empleo ha demostrado no sostenerse siquiera por su propio peso, dado que los puestos de trabajo que se pudieran generar, por bochornosamente cortoplacistas, resultan no dar pie más que a discursos absolutamente populistas con los que ganar la aceptación de una ciudadanía que espera de sus representantes públicos la sensatez mínima como para no prometer humo o burbujas de rápido estallido; cabría preguntarse con qué fines se pretendían dichas simpatías ciudadanas, puesto que el más generoso escenario que imagina quien escribe apunta hacia la consecución de rédito electoral, lo que no merecería más que reproche en lo político.

Pero más allá de estas reflexiones que no por obvias merecen menor mención dado la escasa atención que desde algunos sectores se les ha querido ofrecer en los años de bonanza, el punto de mira y el subrayado se debe poner en la situación del poblamiento diseminado que a día de hoy campa a sus anchas en municipios como Castalla y cuya situación legal, en su inmensa mayoría, resulta o ha resultado en algún momento dudosa. No es intención de este trabajo centrar la atención sobre los propietarios que en un momento dado decidieron levantar en sus terrenos viviendas unifamiliares aisladas siguiendo los procesos que este texto ha pretendido esbozar. Más bien al contrario, a juicio de quien escribe resultaría del todo ilógico pretender perseguir a estas alturas a todos aquellos propietarios que en un momento dado pudieron haber actuado fuera de los marcos legales o incluso de forma contraria a ellos, dado que si hay un responsable de que esto haya sido posible es sin duda la administración local que durante años prefirió dar la espalda a lo que se ha acabado convirtiendo en un auténtico problema. Un problema en algunos casos de encaje legal, pero también un problema en la esfera medioambiental, en la esfera paisajística, y en lo que a la actividad agrícola se refiere al haber reorientado la finalidad de unos terrenos otrora dedicados a la agricultura. Cierto es que el sostén principal del a economía Castallense ha sido y es la industria, además de los servicios en los últimos años, pero la apuesta decidida por estos motores económicos no puede conllevar un auténtico abandono (cuando no sacrificio) a toda una tradición agrícola en torno a la cual se había fraguado un rico legado cultural.

Es por ello que, a juicio de quien escribe, las miradas que pretendan encontrar responsables de estas realidades deben orientarse hacia los poderes públicos que debieron controlar que el desarrollo urbanístico se produjese dentro de los términos ya no sólo legales (que por supuesto también), sino sobre todo lógicos. Carecería de todo 
sentido pretender cobrar los platos rotos a todo un conjunto de ciudadanos que, aunque generadores directos de toda esa urbanización dispersa y espontánea, no hacían más que dejarse llevar por un clima de total permisividad por parte de los poderes municipales, rayana en algunos casos no sólo en la aceptación de los hechos que se producían, sino incluso en el aliento de los mismos. Parece evidente que desde las administraciones no se supo abordar el asunto con la seriedad y responsabilidad que hubiesen sido deseables, realidad ante la cual cabría preguntarse si existieron intereses ocultos más allá de una simple falta de perspectiva ante lo que ahora sabemos que fue un ciclo de expansión económica excesivamente pronunciado debido en buena parte a los esfuerzos del Gobierno por recalentar una economía ya rayana en lo incandescente. A la vista quedan los efectos de aquella política incentivadora del ladrillo materializada en promociones de vivienda a medio terminar, ampliaciones de núcleos urbanos absolutamente innecesarias y de aprovechamiento muy por debajo de lo previsto, y nuevas urbanizaciones de tamaño absolutamente desproporcionado y previsiones totalmente incoherentes.

Los retos de futuro pasan sin duda por encontrar los mecanismos para lograr gestionar una realidad urbanizada difícilmente rectificable, todo ello sin olvidar la acuciante necesidad de que la sociedad en su conjunto comprenda aun a base de traumática experiencia las consecuencias de actuar bajo la embriaguez de la euforia económica, pues sólo así parece posible que esa convicción se traslade también a unos poderes públicos municipales que con total seguridad resultan ser, de entre la jerarquía administrativa española y por la mayor cercanía y contacto con la población, los más susceptibles de reconocer las inquietudes y exigencias de la ciudadanía.

El ejemplo de Castalla aquí resumido no es más que eso, un ejemplo de un fenómeno mucho más generalizado y que en sus distintas facetas se puede reconocer del mismo modo en otros tantos municipios de circunstancias semejantes. Merecería por tanto una reflexión profunda por parte de la ciudadanía en su conjunto sobre el modelo económico-territorial que se pretende y las consecuencias en todos los sentidos que de cada opción se desprendan, no sólo en el corto plazo como se ha venido haciendo sistemáticamente en los últimos años, sino también con imprescindible perspectiva de futuro.

\section{BIBLIOGRAFÍA}

Asociación Imaginando. Presentación del Programa de Ocupación Agrícola y Recuperación de Cultivos. [En línea] 05/07/2012 [Consulta: 21/05/2014]. Disponible en: 〈http://imaginando.org/imaginando-rural/presentacion-del-programa-de-ocupacionagricola-y-recuperacion-de-cultivos/>.

CANO MURCIA, Antonio. El Régimen Jurídico del Suelo No Urbanizable o Rústico. Cendea de Cizur (Navarra): Aranzadi, 2006. pp. 355-356.

CANTÓ LOPEZ, Ma Teresa. La vivienda familiar en el suelo no urbanizable. Madrid: Iustel, 2007. pp. 175-176.

Diario La Verdad. La nueva Ley de Urbanismo entra hoy en vigor en la Comunitat. [en línea]. 20/08/2014 [Consulta: 20/08/2014]. Disponible en:

<http://www.laverdad.es/alicante/201408/20/nueva-urbanismo-entra-vigor20140820104410.html> 
Diario El Mundo. Ladrillo a ladrillo, el mapa de la especulación. [En línea]. Noviembre de 2006. [Consulta: 21/05/2014]. Disponible en:

$<$ http://www.elmundo.es/especiales/2006/11/espana/corrupcion_urbanistica/sospechoso $\underline{\text { s.html }>}$

ESCAPARATEDIGITAL.com. La Conselleria de Territorio y Vivienda legaliza la segunda fase de Castalla Internacional cuando ya hay más de 400 chalets construidos. [En línea]. 06/11/2006 [Consulta: 21/05/2014]. Disponible en:

$<$ http://www.escaparatedigital.com/noticia_detalle.php?id=ufI8rl7857151xmcDWCldM g5br7CFv510KawT3innfwp\&iVR=4>

EuropaPress. Militantes del PP de Castalla (Alicante) denuncian por cohecho y apropiación indebida a su propio alcalde. [en línea]. 19/08/2009. [Consulta:

21/05/2014]. Disponible en: <http://www.europapress.es/nacional/noticia-militantes-ppcastalla-alicante-denuncian-cohecho-apropiacion-indebida-propio-alcalde$\underline{20090819184918 . h t m l>}$

GOYTISOLO, Juan. La destrucción del paisaje. Diario El País [En línea]. 10/08/2014 [Consulta: 10/08/2014]. Disponible en: <http://elpais.com/elpais/2014/07/04/opinion/1404467694_368257.html>

Grupo de Trabajo de UPyD en Castalla. Primeras conclusiones sobre Castalla Internacional. Blog "Castalla Magenta", sección sobre Castalla Internacional [En línea]. 01/05/2014 [Consulta: 21/05/2014]. Disponible en:

<http://castallainternational.blogspot.com.es/2014/05/primeras-conclusiones-sobre$\underline{\text { castalla.html }>}$

Grupo de Trabajo de UPyD en Castalla. UPyD pide información al Ayuntamiento tras la reunión con vecinos de Castalla Internacional. Blog "Castalla Magenta", sección sobre Castalla Internacional [En línea]. 25/03/2014 [Consulta: 21/05/2014]. Disponible en: 〈http://castallainternational.blogspot.com.es/2014/04/reunion-con-el-alcalde-decastalla-para.html $>$

GUINDAL, Mariano. El declive de los dioses. Los secretos de la transición económica española desvelados por un testigo de excepción. $1^{\text {a }}$ Edición. Barcelona: Planeta, 2011.

JEREZ DARIAS, Luis M.; MARTÍN MARTÍN, Víctor O.; y PÉREZ GONZÁLEZ, Ramón. Aproximación a una geografía de la corrupción urbanística en España. Ería: Revista Cuatrimestral de Geografía [En línea]. Departamento de Geografía de la Universidad de Oviedo, 2012, no87, pp.5-18. [Consulta: 21/04/2014]. Disponible en: $<$ http://dialnet.unirioja.es/servlet/articulo?codigo $=4004228>$

Ley 10/2004, de 9 de diciembre, de la Generalitat, del Suelo No Urbanizable. Diari Oficial de la Generalitat Valenciana [En línea], n4.900. [Consulta: 17/03/2014]. Disponible en: 〈http://www.docv.gva.es/datos/2004/12/10/pdf/2004_12638.pdf>

Ley 5/2014, de 25 de julio, de la Generalitat, de Ordenación del Territorio, Urbanismo y Paisaje, de la Comunidad Valenciana. Diari Oficial de la Generalitat Valenciana [en línea], $\mathrm{n}^{\circ} 7.329$. [Consulta: 15/08/2014]. Disponible en: <http://www.docv.gva.es/datos/2014/07/31/pdf/2014_7303.pdf > 
NAVARRO, David. Alicante es la provincia española con más trabajadores en la economía sumergida. Diario Información [En línea]. 01/05/2014. [Consulta:

07/05/2014]. Disponible en:

<http://www.diarioinformacion.com/economia/2014/05/01/alicante-provincia-espanolatrabajadores-economia/1496861.html $>$

NAVARRO, David. La inspección detecta empleo irregular en una de cada cuatro empresas que visita en Alicante. Diario Información [En línea]. 06/05/2014. [Consulta: 07/05/2014]. Disponible en:

<http://www.diarioinformacion.com/economia/2014/05/06/inspeccion-detecta-empleoirregular-cuatro/1498504.html>

Plan General del Término Municipal de Castalla. Portal web de la Conselleria d'Infraestructures, Turisme i Medi Ambient [En línea]. Aprobado el 25 de julio de 2002. [Consulta: 21/05/2014]. Pág.13. Disponible en:

$<$ http://www.cma.gva.es/contenidoHtmlArea/contenido/30231/cas/MemInformativa.pdf $>$

SERRANO, C. La cooperativa de Castalla registra una avalancha de socios tras cerrarse la de IBI. Diario Información [En línea]. 18/01/2011 [Consulta: 19/05/2014]. Disponible en: <http://www.diarioinformacion.com/alcoy/2011/01/18/cooperativacastalla-registra-avalancha-socios-cerrarse-ibi/1085446.html >

SERRANO, C. La fiscalía investiga la devolución del aval de Castalla Internacional. Diario Información [En línea]. 19/10/2012 [Consulta: 21/05/2014]. Disponible en: <http://www.diarioinformacion.com/alcoy/2012/10/19/fiscalia-investiga-devolucionaval-castalla-internacional/1306285.html $>$

SERRANO, C. La promotora de Castalla Internacional quiebra y deja 350 viviendas sin terminar. Diario Información [en línea]. 29/12/2011. [Consulta: 22/05/2014] Disponible en: <http://www.diarioinformacion.com/alcoy/2011/12/29/promotoracastalla-internacional-quiebra-deja-350-viviendas-terminar/1206440.html>

VALOR i VIVES, Enric. Sense la Terra Promesa (Cicle de Cassana, I) [En catalán]. Tàndem, 1999.

VELERT, Sara y MOLTÓ, Ezequiel. Territorio retira el control urbanístico a Catral porque tiene 1.270 casas ilegales. Archivo del Diario El País. 04/10/2006. [Consulta: 31/03/2014]. Disponible en:

<http://elpais.com/diario/2006/10/04/cvalenciana/1159989479_850215.html>

\section{RECURSOS ELECTRÓNICOS}

Banco de datos territorial, movimiento laboral registrado. Contratos según actividad económica (CNAE 1993 y CNAE-2009). En: Instituto Valenciano de Estadística. Disponible en:

$<$ http://www.ive.es/ivepegv/portal_file_c.php?nodourl=http://www.ive.es/ive/bdm/men u.php> [Consulta: 27/04/2014] 
Barómetros del CIS, octubre de 2013 a enero de 2014. [Consulta: 22/04/2014].

Disponibles en: 〈http://www.cis.es/cis/opencm/ES/11_barometros/preguntasfijas.jsp>

Boletín Oficial de la Provincia de Alicante, n²50, 31 de octubre de 2006 [En línea]; pág.14 y sigs. [Consulta: 21/05/2014]. Disponible en: <http://www.dipalicante.es/bop2/pdftotal/2006/10/31-10-06.pdf>

Estimaciones de superficies de cultivo por municipios: superficies según grupo de cultivo y tipo de riego y superficies de los principales cultivos de frutales no cítricos según tipo de riego. Banco de datos territorial del Instituto Valenciano de Estadística (IVE) [En línea]. [Consulta: 18/04/2014]. Disponible en: 〈http://www.ive.es/>

Nomenclátor. Población del Padrón Continuo por Unidad Poblacional. Instituto Nacional de Estadística [En línea]. [Consulta: 19/04/2014]. Disponible en: $<$ http://www.ine.es/nomen2/index.do $>$

Presupuesto municipal de Castalla (1984-2014). Unidad de documentación de la Diputación de Alicante [En línea]. [Consulta: 17/05/2014]. Disponible en:

<http://www.dip-alicante.es/documentacion/presupuesto.asp?municipio=53>

Resultados de las elecciones municipales de 2011 en Castalla. Ministerio del Interior, Gobierno de España [En línea]. 22/11/2011 [Consulta: 17/05/2014]. Disponible en: $<$ http://elecciones.mir.es/resultados2011/99MU/DMU1703905399_L1.htm?d=473\&e=0 $>$

Sede Electrónica del Catastro. Ministerio de Hacienda y Administraciones Públicas [En línea]. [Consulta: 17/04/2014]. Disponible en: 〈https://www1.sedecatastro.gob.es/>

Terrasit (Infraestructura de Datos Espaciales de la Comunidad Valenciana). [Consulta: 15/04/2014]. Disponible en: 〈http://terrasit.gva.es/es/ver>

Vuelos fotogramétricos Americano (1956-1957), Nacional (1980-1986) y PNOA máxima actualidad (2012). Disponible en la fototeca del CNIG:

<http://fototeca.cnig.es/>

(c) Copyright Sergi Esteve Rico, 2014.

(C) Copyright GeoGraphos, 2014.

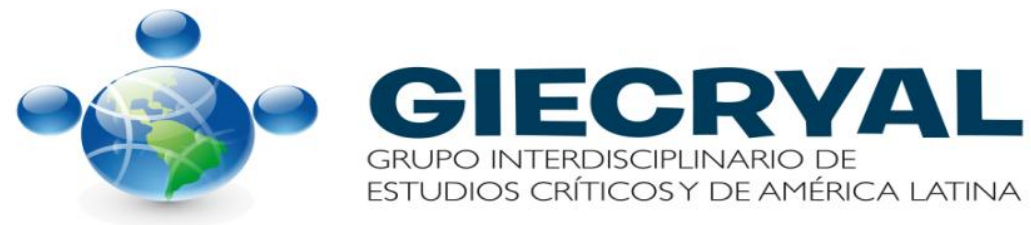

